\title{
EL ALCANCE TEMPORAL DE LA DECLARACIÓN DE INCONSTITUCIONALIDAD DE LAS LEYES CIVILES. ESPECIAL REFERENCIA A LAS VALENCIANAS'
}

\author{
The temporal scope of the declaration \\ of inconstitutionality of the civil laws. \\ Special analysis of the Valencian laws
}

\author{
M. a DOLORES MAS BADÍA \\ Universitat de València \\ dolores.mas@uv.es
}

Cómo citar/Citation

Mas Badía, M. D.(2017).

El alcance temporal de la declaración de inconstitucionalidad de las leyes civiles. Especial referencia a las valencianas. Derecho Privado y Constitución, 31, 317-386. doi: https://doi.org/10.18042/cepc/dpc.31.08

(Recepción: 30/07/2017. Aceptaciòn tras revisión: 18/09/2017. Publicación: 27/1 1/2017)

\section{Resumen}

Se estudia el alcance que debe tener la declaración de inconstitucionalidad en el tiempo, en qué medida debe privar de eficacia hacia el pasado a la ley afectada o, incluso, si puede permitir cierto grado de ultractividad de esta. La doctrina del Tribunal Constitucional se ha elaborado, sobre todo, a partir de casos de índole fiscal o administrativa. Conviene investigar hasta qué punto pueden plantear especialidades los supuestos de carácter civil. La cuestión ha cobrado actualidad a raíz de tres sentencias del Tribunal Constitucional que, en el año 2016, declararon inconstitucionales

Este trabajo ha sido elaborado en el marco del Proyecto de investigación PROMETEO «Derecho civil y europeo», PROMETEOII/2015/014, dentro del Grupo Valenciano de Estudio del Derecho Privado Europeo (GEVDPE), inscrito en el Registro de Estructuras de Investigación de la Universitat de València (ref. GIUV 2013-118). 
las leyes civiles valencianas que regulaban algunos aspectos básicos de las relaciones familiares.

\section{Palabras clave}

Declaración de inconstitucionalidad; nulidad; retroactividad; irretroactividad; leyes civiles.

\section{Abstract}

In this work we analize the significance that the declaration of unconstitutionality must have with regard to time; to which extent it should deprive of efficacy in the past the affected law or even if some degree of future efficacy should be allowed. The doctrine of the Constitutional Court has been created from cases with an administrative or fiscal nature. It's convenient to investigate to which extent the civil cases can suggest specialties. The issue has gained currency as a result of three sentences by the Constitutional Court that in 2016 declared the Valencian civil laws that regulated some basic aspects of family relationships unconstitutional.

\section{Keywords}

Pronouncements of unconstitutionality; retroactivity; non-retroactivity; nullity; civil laws. 


\section{SUMARIO}

I. DELIMITACIÓN DE LA MATERIA OBJETO DE ANÁLISIS Y JUSTIFICACIÓN DE SU OPORTUNIDAD. II. MARCO NORMATIVO. III. LA DOCTRINA DEL TRIBUNAL CONSTITUCIONAL SOBRE EL ALCANCE TEMPORAL DE LA DECLARACIÓN DE INCONSTITUCIONALIDAD DE LAS LEYES EN GENERAL: 1. Planteamiento. 2. Conflictos de competencia. Diferentes soluciones según los actos o disposiciones viciados de incompetencia hayan agotado o no sus efectos. 3. Recurso/cuestión de inconstitucionalidad. El punto de inflexión: la STC 45/1989. 4. El alcance temporal de la declaración de inconstitucionalidad en la jurisprudencia constitucional posterior a la STC 45/1989. Grupos de casos. IV. ANÁLISIS DE LA CUESTIÓN EN RELACIÓN CON LAS LEYES CIVILES EN PARTICULAR. ESPECIAL REFERENCIA A LAS LEYES VALENCIANAS DECLARADAS INCONSTITUCIONALES: 1. Planteamiento. 2. Casos de declaración de inconstitucionalidad sin nulidad de leyes civiles. 3. Casos de limitación del alcance retroactivo de la nulidad de leyes civiles declaradas inconstitucionales: 3.1. La STC 82/2016, relativa a la Ley 10/2007, de 20 de marzo, de Régimen Económico Matrimonial Valenciano. 3.2. Las sentencias que declaran la inconstitucionalidad de algunas leyes autonómicas sobre uniones de hecho, con especial consideración de la STC 110/2016, relativa a la Ley 5/2012, de 15 de octubre, de Uniones de Hecho Formalizadas de la Comunitat Valenciana. 3.3. La STC 192/2016 sobre la Ley 5/2011, de 1 de abril, de la Generalitat, de las relaciones familiares de los hijos e hijas cuyos progenitores no conviven. V. CONCLUSIONES. BIBLIOGRAFíA.

\section{DELIMITACIÓN DE LA MATERIA OBJETO DE ANÁLISIS Y JUSTIFICACIÓN DE SU OPORTUNIDAD}

Una ley declarada inconstitucional puede desplegar efectos. Mientras estuvo vigente, se aplicó, generó obligaciones, derechos y expectativas amparada por la presunción de validez. La sentencia firme de inconstitucionalidad impacta en este panorama. Aunque en el derecho español lleva aparejado, en principio y según doctrina mayoritaria, la nulidad de los preceptos afectados y no su mera derogación - en teoría ambos sistemas son posibles y de ambos ofrece ejemplos el derecho comparado-, sería ingenuo pensar que los problemas se resuelven apelando al viejo brocardo según el cual lo que es nulo no produce efectos. La declaración de inconstitucionalidad no obliga a eliminar 
todo vestigio de eficacia de la disposición censurada. La dificultad estriba en que estos retazos de vida se mueven con frecuencia en una zona de incertidumbre o de sombra más o menos acentuada según el Tribunal Constitucional (TC) haya precisado con mayor o menor cuidado el alcance retroactivo de su sentencia o haya ofrecido al intérprete los criterios para hacerlo. El análisis que me propongo efectuar sitúa al observador en el momento en que la sentencia de inconstitucionalidad es firme y lo invita a reflexionar acerca de la medida en que debe privar de eficacia hacia el pasado a la ley fallida o, incluso, si puede permitirle cierto grado de ultractividad. Dicho de otro modo, si las situaciones que nacieron al amparo de la vigencia de la disposición inconstitucional se rigen, y hasta qué punto, por ella.

En sus primeros años de actividad, el TC eludió entrar con claridad en el asunto pese a ser consciente de su importancia o quizá por serlo. La materia era compleja, el texto de los preceptos constitucionales no era todo lo claro que sería deseable y los sistemas de derecho comparado manifestaban cierta tensión en la práctica. Pero tras esta primera etapa dubitativa, el TC asumiendo su legitimación para precisar, en cada caso, el alcance temporal de su fallo, ha matizado en diversos sentidos la conexión entre declaración de inconstitucionalidad y nulidad absoluta y la eficacia en el tiempo de esta. El TC ha elaborado su doctrina con ocasión, sobre todo, de la resolución de recursos que afectaban a normas o actos de carácter tributario o administrativo. Esto marca de forma significativa el tipo de intereses afectados y de «situaciones consolidadas» sobre cuyo mantenimiento pende la espada de Damocles. Tales intereses y situaciones pueden ser sustancialmente diferentes cuando la sentencia afecta a leyes civiles. Y ello plantea, prima facie, la duda de si pueden trasladarse sin más, o conviene modular de alguna manera, las pautas empleadas para resolver los casos fiscales o administrativos, decantadas a partir de un proceder eminentemente casuístico — como no podía ser de otra manera- del TC. A tal efecto, acaso no sea lo mismo, por ejemplo, tener que devolver o no a los contribuyentes notables cantidades de dinero ingresadas por aplicación de un precepto fiscal inconstitucional con la consiguiente repercusión en el gasto público, o dejar desprotegido un paraje natural al declarar inconstitucional por falta de competencia la disposición que lo tutelaba, que precisar la eficacia retroactiva de la nulidad de la ley que se aplicó para atribuir la custodia de un hijo o para determinar el régimen económico aplicable a un matrimonio o los derechos y obligaciones personales y patrimoniales de los miembros de una pareja de hecho.

Llegados a este punto, la oportunidad del presente análisis se justifica en consideración a varios factores.

En primer lugar, frente a la declaración de inconstitucionalidad de leyes civiles, que se produce no pocas veces por razones de competencia, la doc- 
trina suele focalizar su atención sobre la sensible cuestión competencial sin profundizar en la eficacia en el tiempo de tal declaración, pese a su interés tanto teórico como práctico. Existe cierta laguna en los estudios doctrinales sobre este aspecto que merece ser cubierta. En última instancia está en juego la certidumbre sobre el derecho aplicable y, por tanto, la seguridad jurídica.

En segundo lugar, la cuestión ha cobrado actualidad a raíz de tres sentencias en las que recientemente se han declarado inconstitucionales las leyes civiles valencianas que regulaban algunos aspectos básicos de las relaciones familiares; tres leyes que habían funcionando desde hace años con absoluta normalidad y buena acogida en la sociedad valenciana: STC 82/2016, de 28 de abril (RTC 2016/82), sobre la Ley 10/2007, de 20 de marzo, de Régimen Económico Matrimonial Valenciano; STC 110/2016, de 9 de junio de 2016 (RTC 2016/110), acerca de la Ley 5/2012, de 15 octubre, de Uniones de Hecho Formalizadas de la Comunitat Valenciana; y STC 192/2016, de 16 de noviembre (RTC 2016/192), relativa a la Ley 5/2011 de 1 de abril, de Relaciones Familiares de los Hijos e Hijas cuyos Progenitores no Conviven.

Los fundamentos jurídicos de alguna de estas sentencias presentan ciertas peculiaridades a la hora de fijar el grado de retroactividad o irretroactividad de la declaración de inconstitucionalidad (la utilización que hace el TC del principio de autonomía privada en la STC 82/2016; o del interés superior del menor en la STC 192/2016). Pero, a salvo de esto, no puede decirse que sean innovadoras en relación con la doctrina tradicional sobre el alcance temporal de la declaración de inconstitucionalidad de las normas con rango de ley. ¿Por qué merecen entonces una atención especial? ¿Qué es lo que las dota de sustantividad propia? En todas ellas, el TC ha sido consciente de que se suscitarían problema relativos al grado de retroactividad o irretroactividad de sus pronunciamientos y se ha manifestado sobre la cuestión de modo expreso. Pero lo ha hecho, con algunas excepciones, en términos muy genéricos, y ha dejado en manos del intérprete la aplicación de estas directrices a los problemas concretos que, sin duda, llegarán a los despachos profesionales y quizá a los tribunales. Problemas de derecho privado que afectan tanto a la esfera personal como patrimonial de los particulares: cónyuges, parejas de hecho, terceros que se relacionan con aquellos o padres e hijos. Y esto nos lleva de vuelta a la cuestión que antes esbozaba: la necesidad de adaptar los planteamientos del TC, efectuados habitualmente en relación con materias fiscales, urbanísticas o en general administrativas, a la solución de conflictos concretos de derecho privado. Es al descender de los principios a la solución del caso concreto cuando las leyes civiles declaradas inconstitucionales requieren un esfuerzo especial del intérprete y afloran sus peculiaridades. Por poner un ejemplo, aunque sea en esta fase preliminar del trabajo, la afirmación — tradicional ya en la jurisprudencia constitucional - del respeto o no afección de aquellas situaciones 
consolidadas por el efecto de cosa juzgada o por constituir situaciones administrativas firmes cuando se publica la sentencia de inconstitucionalidad, resulta claramente insuficiente ante situaciones de derecho privado susceptibles de seguir produciendo efectos, tales como la custodia de un hijo o los derechos y obligaciones de los cónyuges. Aún hay otro factor que no hay que perder de vista al fijar el alcance de la retroactividad o irretroactividad de la sentencia de inconstitucionalidad: la causa de esta. Puede ser relevante que aquella obedezca a defectos procedimentales o de incompetencia, o, por el contrario, a la lesión de los derechos fundamentales y libertades tutelados por la Constitución española (CE). En este punto, el caso valenciano resulta, de nuevo, peculiar si meditamos en que estas mismas leyes se habrían considerado constitucionales de haber sido dictadas por otra comunidad autónoma cuya competencia se entendiera amparada por la interpretación tradicional del «allí donde existan» del art. 149.1.8. ${ }^{\text {a }} \mathrm{CE}$ y que no faltan argumentos para defender, ante la idiosincrasia de la Comunitat Valenciana, que hubiera sido conveniente una interpretación evolutiva de este precepto que salvara la constitucionalidad de las referidas leyes, aplicadas con normalidad durante largos años, como esperaban muchos valencianos. Veremos si debe ser un factor esencial a la hora de concretar en qué medida la declaración de inconstitucionalidad debe afectar a los actos o derechos que se produjeron o nacieron a su amparo.

Tras la introducción (epígrafe I), el estudio comienza por definir el marco normativo, constituido por la CE y el desarrollo efectuado por la Ley Orgánica 2/1979, de 3 de octubre, del Tribunal Constitucional (LOTC, epígrafe II). Se asciende un peldaño más analizando la práctica del TC con el fin de decantar, a partir de sus sentencias, unos criterios rectores sobre la determinación del alcance temporal de la declaración de inconstitucionalidad de las normas con rango de ley en general (epígrafe III). Hecho esto será el momento de contrastar las conclusiones alcanzadas con la situación que se plantea cuando la ley declarada inconstitucionalidad tiene carácter civil. A tal efecto, se examinan los pronunciamientos más relevantes del TC en este campo, con especial atención a los recaídos recientemente sobre las leyes civiles valencianas (epígrafe IV).

\section{MARCO NORMATIVO}

Las primeras claves para el análisis hay que buscarlas en la propia $\mathrm{CE}$ y en el desarrollo efectuado por la LOTC, aunque sus previsiones normativas sean escasas e insuficientes para abordar los complejos problemas que la prác- 
tica plantea (Gómez Montoro, 2001: 582)². El análisis de estas normas puede sintetizarse en las siguientes conclusiones.

a. La cosa juzgada como límite de la retroactividad. De acuerdo con el art. 161.1.a) CE, la declaración de inconstitucionalidad de una norma con rango de ley, interpretada por la jurisprudencia, afectará a esta, si bien las sentencias recaídas no perderán el valor de cosa juzgada. Se formula aquí un límite claro a la eficacia hacia el pasado de la declaración de inconstitucionalidad: la cosa juzgada, esto es, los fallos de sentencias firmes basados en la disposición que después se ha declarado contraria a la CE. Tal límite constituye una aplicación concreta e insoslayable del principio de seguridad jurídica garantizado por el art. 9.3 CE, que exige un mínimo de certeza y de estabilidad en las relaciones y situaciones jurídicas (Cappelletti, 1978: 115)3. El art. 40.1 LOTC, tras corroborar este límite, establece una salvedad en los supuestos de normas penales o sancionadoras más beneficiosas para el condenado o sancionado.

b. El valor de cosa juzgada de las sentencias del TC y la vinculación de los poderes públicos. Todas las sentencias del TC tienen valor de cosa juzgada, tanto en sentido formal como material ${ }^{4}$. El art. 164.1 CE señala que lo tienen a partir del día siguiente de su publicación en el $B O E^{5}$. El art.

2 Palabras que reflejan el sentir generalizado de la doctrina. De los graves problemas que suscita la cuestión de los efectos de la sentencia constitucional, «cuya resolución se complica por la habitual insuficiencia de la regulación legal» trata con perspectiva de derecho comparado Fernández Rodríguez (2007: 115 y ss.).

3 Durante la tramitación parlamentaria de la LOTC el Grupo Parlamentario UCD en el Senado presentó la enmienda número 40, que propugnaba añadir al art. 40.1: «Tampoco dichas sentencias producirán efectos respecto de las relaciones jurídicas ya consumadas en aplicación de la ley declarada inconstitucional, salvo especial pronunciamiento del fallo» (BOCG. Senado, Serie II, núm. 21, 21.8.1979). Se justificaba con base en la seguridad jurídica. La enmienda fue rechazada, aunque, como veremos, la práctica del TC ha evolucionado en este sentido.

4 Sobre las especialidades del efecto de cosa juzgada de las sentencias recaídas en procesos de constitucionalidad, puede atenderse a la síntesis que ofrecen De la Cueva Aleu (2010: 427 y ss.) o Gómez Montoro (2001: 559 y ss.).

5 De esta declaración no cabe extraer que las sentencias del TC solo tengan eficacia desde su publicación. Así es frente a terceros, pero inter partes son eficaces desde su notificación, como cualquier sentencia. En este sentido, Rubio y Aragón (1981: 868) o Bocanegra Sierra (1982: 87-88). De la Cueva Aleu (2010: 427) va un paso más allá y afirma que «no es posible que los poderes públicos ni los particulares puedan hacer caso omiso de la Sentencia si la conocen por otros medios antes de su publicación». 
38.1 LOTC insiste en el valor de cosa juzgada; sin embargo, su tenor muestra algunas diferencias con el del art. $164 \mathrm{CE}$. En primer lugar, la concordancia del texto del art. 38.1 LOTC con el del art. 164.1 CE presenta una grieta en la fijación del momento a partir del cual la sentencia despliega el efecto de cosa juzgada que, según la CE, es el día posterior al de la publicación en el $B O E$ y el art. 38.1 LOTC refiere al mismo día de la publicación. En segundo lugar, hay una alusión a que las sentencias del TC recaídas en procesos de inconstitucionalidad «vincularán a todos los Poderes Públicos». Esta idea se repite, en el art. 61.3 LOTC respecto de las sentencias que resuelven conflictos de competencia entre el Estado y las comunidades autónomas o de estas entre sí. En cualquier caso, no parece que ese inciso modifique las reglas contenidas en el art. 164.1 $\mathrm{CE}^{6}$.

c. La eficacia erga omnes de las sentencias del TC. El art. 164.1, in fine CE, establece que, de entre todas las sentencias del TC, aquellas que declaran la inconstitucionalidad de una ley o norma con fuerza de ley y todas las que no se limiten a la estimación subjetiva de un derecho, además de valor de cosa juzgada gozan de eficacia «erga omnes» desde su publicación en el $B O E$. Esto significa que la sentencia tiene «fuerza (a semejanza) de ley», aunque de signo opuesto, esto es, capacidad para eliminar la disposición inconstitucional con efectos generales, transformando de este modo el ordenamiento jurídico ${ }^{7}$. Pero lo que no puede deducirse del art. 164.1 CE es el alcance temporal de los efectos de la sentencia, que es precisamente el aspecto sobre el que tratamos de indagar. Queda este indeterminado en el precepto.

d. Las consecuencias de la declaración de inconstitucionalidad sobre la ley afectada: el binomio inconstitucionalidad/nulidad. La CE establece la pérdida de vigencia de la ley en la parte afectada por la inconstitucionalidad (cfr. art. 164.2 «a contrario»), sin especificar en qué se traduce esa pérdida de

6 Acerca de los problemas interpretativos del inciso referido a la «vinculación», sobre todo si se la intenta conectar con la categoría de la «Bindungswirkungen» alemana, reflexiona Bocanegra Sierra (1982: 95 y ss). Para unos breves apuntes de derecho comparado, véase Fernández Rodríguez (2007: 118 y ss.). Un buen resumen de las principales cuestiones que suscita el efecto de la vinculación puede encontrarse en De la Cueva Aleu (2010: 430 y ss.).

7 Mientras el art. 161.1 CE asocia los efectos generales a las sentencias estimatorias de la inconstitucionalidad (a las que deben unirse por razones de analogía las sentencias interpretativas), el art. 38.1 LOTC no discrimina entre sentencias estimatorias y desestimatorias. Pese a ello, hay acuerdo doctrinal en dejar a estas últimas al margen de la predicada eficacia general. Resume los argumentos que apoyan esta conclusión Gómez Montoro (2001: 568 y 573). 
vigencia. La doctrina ha señalado que, en teoría, podría encontrar acomodo en una de estas dos categorías conceptuales: derogación o nulidad. La STC 14/1981, de 29 de abril (RTC 1981/14) se refiere, en términos generales, a la diferencia entre la derogación y la inconstitucionalidad en clave de nulidad: «El tratamiento de la derogación y el de la inconstitucionalidad varían porque la derogación priva de eficacia a la norma desde la vigencia de la disposición derogatoria ${ }^{8}$, mientras que la inconstitucionalidad de las leyes posteriores a la Constitución conlleva la sanción de la nulidad con ineficacia originaria, si bien dentro de un respeto a situaciones consolidadas en los términos que se coligen de los arts. 39.1 y 40.1 de la LOTC» (Fundamento Jurídico [FJ] 4).

De entre los posibles sentidos de la pérdida de vigencia de los preceptos declarados inconstitucionales, la LOTC se decanta por su nulidad (art. 39.1 LOTC). La pregunta clave es hasta qué punto debe asimilarse esta nulidad con la eficacia ex tunc ${ }^{9}$. Para responderla caben, en principio, dos opciones. Partir de una concepción apriorística que identifique nulidad absoluta con efi-

8 Es lo que sucede con las normas preconstitucionales afectadas por la Disposición Derogatoria $3 \mathrm{CE}$. Al contravenir la $\mathrm{CE}$, dejan de ser aplicables a partir de la entrada en vigor de esta. Tanto el TC (véase la STC 39/2002, de 14 de febrero [RTC 2002/39]) como el TS (entre otras, STS, Sala Civil, de 14 de septiembre de 2009 [ROJ: STS 5417/2009]) han declarado que, cuando la duda de constitucionalidad se plantea en relación con normas preconstitucionales, el órgano judicial puede suscitar la correspondiente cuestión de inconstitucionalidad ante el TC, pero también puede examinar y resolver por sí mismo la eventual contradicción de la norma con el ordenamiento constitucional.

9 Díez-Picazo (1990: 265) escribe: «Dar por sentado que toda nulidad absoluta, incluida la de la ley, deba operar ex tunc significa lisa y llanamente trasladar al derecho constitucional positivo una construcción teórica abstracta de orden pandectista, cuyo ámbito de aplicación natural es el derecho privado; o, en el mejor de los casos, significa trasladar al juicio de la ley la regulación legal que, sobre la base de esa concepción jurídico-privada, gobierna el juicio del acto administrativo (art. 47 LPA). En otras palabras, creer que toda nulidad absoluta opera ex tunc implica hacer interpretación constitucional bien a partir de puras categorías teórico-generales, bien a partir de una regulación infraconstitucional. De aquí, que sea preciso comprobar que la eficacia ex tunc de la nulidad de la ley es coherente o, al menos, compatible con las características constitucionales de la ley misma». Insiste en la imposibilidad de aplicar en todos sus términos la construcción de la nulidad de la teoría general del derecho, Fernández Rodríguez (2007: 124), que se refiere a «una nulidad sometida a las peculiaridades propias del derecho Procesal Constitucional». 
cacia ex tunc conforme con el viejo brocardo quod nullum est, nullum effectum producit, de modo que en el naufragio de la ley inválida por inconstitucional sucumbirán todas las situaciones nacidas bajo su amparo (salvo las que disfruten del salvavidas de la cosa juzgada). O admitir que una ley nula puede desplegar efectos. Si se acepta esto, el problema será concretar su alcance en el tiempo. Es una labor que queda en manos del propio TC, que opera casuísticamente, aunque a partir de sus sentencias pueden decantarse algunos criterios rectores, como luego veremos. Si el TC no ha sido lo suficientemente preciso, entrará en juego la labor interpretativa de los tribunales ordinarios al resolver las controversias que se les planteen.

En el derecho comparado, los efectos en el tiempo de la declaración de inconstitucionalidad varían según el sistema que se adopte. La doctrina considera, en el common law, el sistema norteamericano de nulidad absoluta ${ }^{10}$, cuya esencia quedó formulada por el juez John Marshall en la Sentencia Marbury vs. Madison (1803), que constituye la primera aplicación del procedimiento del judicial review ${ }^{11}$. En el entorno del civil law se distingue entre el modelo austriaco, de inspiración kelseniana, de derogación o anulación, y el alemán,

10 Como explica Cappelletti (1978: 105), en el sistema norteamericano, según la concepción tradicional, la ley inconstitucional, en tanto contraria a una norma superior se considera nula absolutamente y, por tanto, ineficaz. El juez que ejercita el poder de control no anula, sino que declara una preexistente nulidad de aquella. El juez ordinario debe limitarse a no aplicar la ley inconstitucional al caso concreto; el control de constitucionalidad no tiene, a diferencia del sistema austriaco, eficacia erga omnes, sino solo inter partes, aunque esta afirmación debe ser sustancialmente matizada, en especial cuando se trate del control ejercido por el TS, a la vista del principio stare decisis, de la vinculación al precedente.

11 En ella puede leerse lo siguiente (utilizo en la cita la traducción realizada por García de Enterría [1981: 80, nota 118]): «Es una proposición demasiado simple que pueda discutirse que o bien la Constitución controla cualquier acto legislativo que la contradiga o bien el legislativo podrá alterar la Constitución por una Ley ordinaria. Entre esa alternativa no hay término medio. O la Constitución es un derecho superior o supremo, inmodificable por los medios ordinarios, o está al mismo nivel que los actos legislativos, y como cualquier otra Ley, es modificable cuando al Legislativo le plazca hacerlo. Si el primer término de la alternativa es verdadero, entonces un acto legislativo contrario a la Constitución no es derecho; si fuese verdad el segundo término, entonces las Constituciones escritas serían intentos absurdos por parte del pueblo, de limitar un poder que por su propia naturaleza sería ilimitable. Ciertamente, todos los que han establecido Constituciones escritas contemplan a éstas como formando el derecho supremo y fundamental de la nación, y, consecuentemente, la teoría de los respectivos gobiernos debe ser que una Ley del legislativo ordinario que contradiga a la Constitución es nula». 
de nulidad absoluta, con el que guarda muchos puntos en común el sistema español ${ }^{12}$.

Sin embargo, la idea de la que cabe extraer consecuencias más fructíferas y que ahora quiero destacar es la siguiente: cuando el patrón que se adopta parte, ab initio, de una eficacia solo pro futuro o ex nunc de la declaración de inconstitucionalidad (sistemas de derogación o anulación, en que el control de inconstitucionalidad tiene carácter constitutivo de la invalidez y de la consecuente ineficacia de las leyes inconstitucionales — es el caso del sistema austriaco-), acaba matizándose para admitir ciertos efectos retroactivos. Por el contrario, cuando se parte de modelos que encajan inicialmente con una eficacia ex tunc, como ocurre con la nulidad absoluta (sistemas en que la sentencia de inconstitucionalidad solo tiene carácter declarativo de una preexistente invalidez — sistemas norteamericano y alemán—), termina por admitirse cierto grado de irretroactividad; es decir, se limita en cierta medida la eficacia en el tiempo de la nulidad para evitar las consecuencias indeseables que podría tener no hacerlo así, muy especialmente en aquellos supuestos en que la ley inválida se ha aplicado con normalidad y durante largo tiempo en la práctica, pudiendo quedar ahora destruidos todos sus efectos si no se admitieran temperanzas a la retroactividad. No existen, pues, en la práctica, sistemas puros. Y no existen porque no resultarían funcionales ${ }^{13}$. El caso español no es una excepción, como podrá apreciarse al analizar la jurisprudencia constitucional. Aunque carecemos, a diferencia de otros ordenamientos de nuestro entorno jurídico, de una norma clara en la que de modo expreso se habilite al TC para proceder a esta flexibilización, ello, sin embargo, no ha frenado la evolución de la jurisprudencia del TC en el sentido apuntado ${ }^{14}$. Esta visión relativista,

12 Puede encontrarse una exposición más profunda sobre estos sistemas en Díez-Picazo (1990: 262), Cappelletti (1978: 106) o García de Enterría (1981: 84), entre otros.

13 En este sentido se pronuncian Pelegrí Girón (1988: 3533-3534), Gómez Montoro (2001: 614 y ss.) o Fernández Rodríguez (2007: 138 ss.). González-Vargas Ibáñez (2009: 367) destaca cómo la posibilidad de supuestos de nulidad con efectos ex nunc y la diferenciación entre inconstitucionalidad con o sin nulidad no solo funciona en la mayor parte de los Estados europeos, sino que, incluso en varios países del Este de Europa, se considera una nueva tendencia jurídica de progreso.

14 En el Proyecto de Ley Orgánica de Modificación de la LO 2/1979, de 3 de octubre, del TC, que daría lugar a la LO 6/2007, de 24 de mayo, se proponía un nuevo texto para el art. 39.1 LOTC, del siguiente tenor: «Cuando la sentencia declare la inconstitucionalidad, declarará igualmente la nulidad de los preceptos impugnados o cuestionados. No obstante, motivadamente y para preservar los valores e intereses que la Constitución tutela, la sentencia podrá declarar únicamente la inconstitucionalidad o diferir los efectos de la nulidad por un plazo que en ningún caso será superior a tres 
alejada de planteamientos dogmáticos que se han mostrado claramente insuficientes para resolver el problema de la retroactividad/irretroactividad de la declaración de inconstitucionalidad ${ }^{15}$, es una de las conclusiones más importantes a las que conduce el estudio de la materia.

También en la jurisprudencia del Tribunal de Justicia de la Unión Europea (TJUE) y del Tribunal Europeo de Derechos Humanos (TEDH), que cumplen una función paraconstitucional, puede apreciarse la importancia de que el Tribunal pueda delimitar los efectos temporales de la declaración de nulidad de la norma ${ }^{16}$. El artículo 264 del Tratado de Funcionamiento de la Unión Europea (TFUE) ${ }^{17}$ (antiguo art. 231 TCE), tras establecer que «(s)i el recurso fuere fundado, el Tribunal de Justicia de la Unión Europea declarará nulo y sin valor ni efecto alguno el acto impugnado», añade: «Sin embargo, el Tribunal indicará, si lo estima necesario, aquellos efectos del acto declarado nulo que deban ser considerados como definitivos». Así pues, en el acervo comunitario se habilita de forma expresa al TJUE para que pueda matizar el alcance retroactivo de la sentencia anulatoria, aunque aquel no se ha prodigado mucho en esta labor. Lo hizo en la STJCE de 8 de abril de 1976, caso Defrenne $\mathrm{II}^{18}$, sobre igualdad salarial entre hombres y mujeres para un mismo

años» (BOCG. Congreso de los Diputados, serie A, núm. 60-1, 25.11.2005). Sin embargo, el cambio no prosperó, ni siquiera, en lo que a la nulidad diferida se refiere, reduciendo el plazo de tres años a uno, como se sugería en la enmienda núm. 57, del Grupo Parlamentario Popular en el Congreso (BOCG. Congreso de los Diputados, serie A, núm. 60-7, 23.2.2006).

15 Sobre la insuficiencia de los planteamientos dogmáticos reflexiona Caamaño Anido (1997: 169 y ss.).

16 Alonso García (1989: 265 y ss.) destaca cómo el Tribunal Europeo, superando el tenor literal de la norma habilitante, no se ha limitado a «definir los efectos de la nulidad para el período comprendido entre la adopción de la norma o acto anulado y la fecha de la Sentencia», sino que «no ha dudado en extender su poder de definición hacia el futuro, manteniendo en vigor los efectos de un reglamento anulado para un período posterior a su Sentencia, en tanto no se adoptaran las medidas de ejecución de la misma» —SSTJCE Comisión vs. Consejo de 5 de junio de 1973 (81/72), 6 de octubre de 1982 (59/81) y 28 de junio de 1988 (7/87).

17 DOUE C 83/163, de 30.3.2010.

18 ECLI:EU:C:1976:56. García de Enterría (1989: 7-8) califica la resolución como la primera en la historia del TJCE que establece una típica jurisprudencia prospectiva. La sentencia trae causa de una petición de decisión prejudicial planteada por la Cour du travail de Bruselas. Parte del litigio entre una azafata de vuelo y su empresa, referente a una indemnización reclamada por la demandante en el procedimiento principal, debido a que, durante varios años, fue víctima de una discriminación en materia 
trabajo, en la que elude los efectos retroactivos de la sentencia, que hubiera obligado a revisar las remuneraciones percibidas hasta la fecha conforme con la disposición anulada en relación con numerosos países y trabajadores que podrían haberla hecho valer ${ }^{19}$. Sin embargo, la doctrina especializada ha detectado una regresión en la jurisprudencia del TJUE, que tras el caso Defrenne II ha derivado hacia posiciones más conservadoras desde el punto de vista dogmático, de afirmación del principio de retroactividad, salvo que el Estado miembro solicite expresamente esta limitación y se den unos requisitos muy estrictos difíciles de cumplir ${ }^{20}$.

de retribución, en relación con sus compañeros de sexo masculino, que realizaban idéntico trabajo como «auxiliares de vuelo».

19 La sentencia, tras declarar la eficacia directa de la norma europea que prohíbe la discriminación salarial, directa o indirecta, por razón de sexo (art. 119 del Tratado CEE, actual art. 157 TFUE) y que vincula a todas las autoridades públicas, convenios colectivos e, incluso, contratos entre particulares, dedica los fundamentos de derecho 69 a 75 a precisar sus efectos en el tiempo. Para matizar la retroactividad, hace hincapié en las graves consecuencias de carácter económico que pueden derivarse de la sentencia, pues, si no se limitaran sus efectos en el tiempo, podría desencadenar una avalancha de acciones reclamando derechos con carácter retroactivo; «habida cuenta del elevado número de personas interesadas, tales reclamaciones, imprevisibles para las empresas podrían tener graves consecuencias sobre la situación económica de éstas, hasta el punto de provocar la quiebra de algunas de ellas». Reconoce, por otra parte, que durante largo tiempo las partes interesadas se vieron impulsadas a mantener prácticas contrarias al art. 119 del Tratado si bien no prohibidas por su derecho nacional, alentadas por la falta de interposición, por parte de la Comisión, de recursos por incumplimiento de los Estados miembros cuyo derecho interno no se acomodaba a la exigencia de no discriminación. Tal proceder pudo consolidar una impresión equivocada acerca de la eficacia directa de la norma. Las anteriores se conjugan con una tercera consideración que atiende a la dificultad práctica de determinar cuáles hubieran sido los niveles retributivos para cada trabajo de haber sido conscientes las empresas de la necesidad de prever igual remuneración por igual trabajo. A la vista de tales razonamientos, el TJCE concluye limitando los efectos en el tiempo de la sentencia, que no podrá sustentar reclamaciones relativas a períodos de retribución anteriores a la misma, «salvo en lo que se refiere a los trabajadores que, con anterioridad, hayan entablado alguna acción judicial o formulado alguna reclamación equivalente».

Así, Caamaño Anido (1997: 177 y ss.); González-Vargas Ibáñez (2009: 361 ss.), que trata de un informe elaborado a iniciativa del Gobierno alemán, cuyo objetivo era corregir esta última tendencia del Tribunal de Luxemburgo; o Ugartemendía-Bengoetxea (2014: 451), que tras recordar que la limitación temporal de las sentencias del TJUE es competencia exclusiva de dicho tribunal —asunto Blaizot $v$ s. Universidad de Lieja, Sentencia de 2 de febrero de 1988, o Evangelischer Krank —enhausverein 
El TEDH, por su parte, aplicó la doctrina que permite matizar el alcance retroactivo de sus sentencias a partir de la Sentencia de 13 de junio de 1979, caso Markx, sobre igualdad de los hijos matrimoniales y no matrimoniales, relativa a un precepto del Código Civil (CC) belga que establecía diferencias en el plano sucesorio y que se declaró contrario a varios preceptos del Convenio Europeo de Derechos Humanos (CEDH; en concreto, los arts. 8, 14 y art. 1 del protocolo primero).

Volviendo a la CE, esta ni prohíbe ni exige los efectos retroactivos de la declaración de inconstitucionalidad. Dicho de otro modo, no establece cuál debe ser la eficacia de la sentencia en el tiempo. Que el texto de la CE ofrece margen interpretativo lo prueban las diferentes posiciones doctrinales que se han mantenido ${ }^{21}$ y la propia evolución que se observa en la jurisprudencia constitucional. A mayor concreción, desciende la LOTC, que sí proporciona cierto anclaje de derecho positivo en relación con esta cuestión. Así, en las sentencias que resuelven conflictos de competencia, faculta de modo expreso al TC para disponer lo que fuera procedente respecto de las situaciones de hecho o de derecho creadas al amparo de la disposición, resolución o acto viciados de incompetencia (art. 66 LOTC) ${ }^{22}$. Es decir, le permite matizar los efectos temporales de la nulidad. En cambio, no hay una norma que se refiere al alcance en el tiempo de la declaración de inconstitucionalidad de las leyes o normas con rango de ley, derivada de la resolución de cuestiones o recursos de inconstitucionalidad (salvo el límite constituido por la cosa juzgada —arts. 161.1.a) CE y 40.1 LOTC_-), aunque sería deseable que en un futuro se incorporase a la LOTC. Pese a ello, como veremos, la doctrina del TC ha evolucionado hasta admitir la misma legitimación en estos casos y la ha ejercido alejándose de un entendimiento estricto de la nulidad que lo hubiera conducido, en contra de lo razonable, a invalidar todas las situaciones jurídicas surgidas desde la entrada en vigor de la ley, salvo las amparadas por el límite de la cosa juzgada.

Wien, Sentencia de 9 de marzo de 2000 [Rec. I-1157 y Rec. 379 respectivamente]constata que ha sido muy raramente aplicada.

21 Sobre las diferencias doctrinales diez años después de dictarse la CE, véase Pelegrí Girón (1988: 3535-3537).

22 Aunque el art. 66 LOTC se ubica en sede de regulación de los conflictos positivos de competencia, sus normas son extensibles a la impugnación de disposiciones sin fuerza de ley y resoluciones de las comunidades autónomas prevista en el artículo 161.2 CE, por remisión del art. 77 LOTC. También se ha preocupado la LOTC de la legitimación del TC para precisar la eficacia temporal de su fallo respecto de las sentencias de amparo [art. 55.1.a) LOTC]. 


\section{LA DOCTRINA DEL TRIBUNAL CONSTITUCIONAL SOBRE EL ALCANCE TEMPORAL DE LA DECLARACIÓN DE INCONSTITUCIONALIDAD DE LAS LEYES EN GENERAL}

\section{PLANTEAMIENTO}

Si hacemos tránsito desde lo que prescriben las normas de la CE y la LOTC a su interpretación y aplicación por el TC, obtenemos unas valiosas conclusiones que añadir a las anteriores. A la vista de la jurisprudencia constitucional, de ningún modo cabe entender la alusión a la nulidad — categoría jurídica ya de por sí conflictiva y de perfiles no siempre claros-, en el art. 39 LOTC, como sentenciadora de que lo que es nulo no produce efectos. El TC, en sus sentencias, ha atemperado por distintas vías tanto el automatismo de la secuencia inconstitucionalidad-nulidad como la eficacia hacia el pasado de esta declaración de nulidad. Las leyes inconstitucionales no siempre se declaran nulas y cuando se afirma su nulidad se dejan a salvo - con distinto alcance según los casos- ciertos efectos. La práctica del TC descrita adopta, como premisa implícita, determinada interpretación del art. 40.1 LOTC, según la cual, dejando a un lado aquellos procesos resueltos mediante sentencia firme o, si se prefiere, con valor de cosa juzgada (a los que acaban equiparándose los supuestos de firmeza administrativa), que no pueden ser revisados, el TC es libre para concretar el alcance en el tiempo de la nulidad de las disposiciones declaradas inconstitucionales ${ }^{23}$. Bien entendido que esta libertad no significa

23 Así lo expresé en Mas Badía (2016: 7). Alonso García (1989: 255-256) opina que del art. 40 LOTC se extrae «una consecuencia importante: la anulación de una norma con rango de ley, con la salvedad apuntada en la segunda parte del párrafo recién citado, en ningún caso puede permitir revisar actos de aplicación resueltos por Sentencia firme. Esto es evidente. Lo que queda en el aire es lo que sucede con relación al resto de los actos de aplicación no incluidos en esa categoría de «resueltos por Sentencia firme»». Apunta dos posibles interpretaciones del art. 40.1 LOTC: entender que impone, contrario sensu, la posibilidad de revisar los actos de aplicación no resueltos por sentencia firme; o interpretar que se ciñe a establecer un límite infranqueable: la imposibilidad de revisión de actos resueltos por sentencia firme, de manera que para el resto de los actos el TC sería libre para modular la eficacia en el tiempo de su sentencia anulatoria. Por su parte, Díez-Picazo (1990: 266-267) se refiere a la posibilidad constitucional de que la declaración de inconstitucionalidad de la ley no posea efectos ex tunc, lo que "daría pie en ciertos casos a una interpretación más restrictiva del art. 40.1 LOTC, que le hiciera decir, por lo demás, lo que literalmente dice: que la declaración de inconstitucionalidad no permite revisar procesos fenecidos, sin que de esa proposición negativa haya de inferirse siempre y necesariamente otra afir- 
arbitrariedad, pues toda modulación de dicha eficacia debe fundamentarse jurídicamente con base en principios generales que tengan fuerza suficiente para justificarla. Con ello, se expande la regla que el art. 66 LOTC refiere a los conflictos positivos de competencia y se opera, en general, conforme con el mismo criterio. Esta interpretación es coherente con la presunción de validez y la ejecutividad de que gozan las leyes. Si a esto se une que la ley declarada inconstitucionalidad estuvo vigente y se aplicó, nos situaremos de lleno ante el principio general de seguridad jurídica (art. 9.3 CE). Porque la previsibilidad de que las conductas de los afectados se rigieran por esta ley es innegable, sin que sea irrelevante la mayor o menor tardanza del TC en dictar sentencia ${ }^{24}$. Sea

mativa de la forzosa retroacción de la declaración de inconstitucionalidad misma. Dicho de otro modo, el silencio de la CE en cuanto a la eficacia temporal de la declaración de inconstitucionalidad unido al peculiar status constitucional de la ley permitirían afirmar la legitimidad de la modulación por el TC de los efectos en el tiempo de sus sentencias, tal como ha comenzado a hacer recientemente; y ello sin perjuicio de que, como regla general, la declaración de inconstitucionalidad haya de presumirse con efectos ex tunc, habida cuenta de que la lectura de los arts. 39.1 y 40.1 LOTC empuja en esa dirección tal como sugiere la doctrina mayoritaria».

24 Este factor no debe perderse de vista al fijar el alcance temporal de la declaración de inconstitucionalidad. La cuestión no ha pasado desapercibida en la doctrina. Oubiña Barbolla (2012: 146-147) destaca la inseguridad jurídica que puede traer consigo una respuesta tardía del TC, dado que la duda que pesa sobre la constitucionalidad de un precepto legal cuando se interpone un recurso o cuestión de inconstitucionalidad no impide, salvo excepciones de suspensión, que la ley siga aplicándose diariamente por los operadores jurídicos y que los órganos jurisdiccionales ordinarios la utilicen en su función jurisdiccional de resolución de conflictos. Concluye subrayando la contradicción que supone que, siendo competencia del TC controlar las dilaciones indebidas del proceso, garantizando así el derecho fundamental a un proceso justo y eficaz (art. 24.2 CE), se convierta en la práctica en uno de los órganos jurisdiccionales cuya actividad es contraria a este derecho fundamental. También Balaguer Callejón (2001: 161-162) llama la atención acerca de las repercusiones de una excesiva duración en la tramitación del recurso de inconstitucionalidad: «En tanto en cuanto la duración media de estos procesos supera los cinco años, el TC se ve impelido a dictar una sentencia que necesariamente gradúe unos efectos que, de retrotraerse, deberían revisar situaciones muy consolidadas en el tiempo». Trae a colación la opinión del magistrado Cruz Villalón vertida en un voto particular formulado en la STC 206/97, donde razona que «a la sentencia que antecede le cabe el dudoso honor de ser la primera que dicta este Tribunal transcurridos diez años desde la interposición del correspondiente recurso, constándonos ya que no va a ser la única. [...] La garantía jurisdiccional de la constitucionalidad de las leyes, en definitiva, la fuerza normativa de la CE, se ve sin duda afectada cuando el único Tribunal con facultad para declarar la nulidad de 
como sea, sería conveniente que se modificara el art. 40.1 LOTC para dotar de un apoyo legal más claro y directo al proceder del TC. Queda finalmente la cuestión de determinar si existe una relación de regla general/excepción entre la eficacia retroactiva o ex tunc y la conservación de determinados efectos de la ley declarada inconstitucional. La gran mayoría de los autores se inclinan por considerarlo así con base en el art. 40 LOTC ${ }^{25}$. Bocanegra Sierra (1982:117), Alonso García (1989: 263-264), García de Enterría (1989: 11), Díez-Picazo (1990: 267), Montoro Chiner (1990: 226), Punset Blanco (1995: 44 y ss.), Garrorena Morales, A. (1999: 359 y ss.), Gómez Montoro (2001: 616-617), González-Varas Ibáñez (2009: 365) y Pérez Tremps (2016: 64). Por otra parte, de las sentencias del TC se extrae la idea de que la irretroactividad, en mayor o menor grado, solo se establece cuando se consideran indeseables las consecuencias de la retroactividad.

El TC habrá de proceder de forma casuística y establecer los matices de la retroactividad, a la vista del caso concreto, de los intereses en juego y de los principios jurídicos involucrados. Pero esto, que manifiesta una conveniente flexibilidad acorde con la imposible reducción de la solución a fórmulas absolutas, no obsta a la posibilidad de decantar, a partir del estudio de sus sentencias, unos criterios rectores interpretativos que guíen la solución de los casos que se vayan planteando, sin perjuicio de que en cada uno de estos se efectúe una valoración ponderada en atención a las circunstancias que en ellos concurran. En muchas sentencias se vislumbra incluso un esfuerzo notable para «intentar construir una doctrina abstracta de los efectos de la nulidad en el control de normas más que contentarse en una argumentación pragmática» ${ }^{26}$.

Cuando el TC no haya fijado en su sentencia los concretos límites temporales de la declaración de inconstitucionalidad de los preceptos afectados será tarea de los jueces y tribunales ante quienes eventualmente se planteen controversias, concretar el alcance de esa retroactividad (véanse, entre otras, SSTS, Sala Tercera, de 15 de julio de 2000 y de 14 de junio de 2004 [ROJ: STS 5880/2000 y ROJ: STS 4069/2004, respectivamente]) ${ }^{27}$. Para ello debe-

una ley debe emplear diez años en la tarea. Hay momentos en los que la cantidad se transforma en calidad, y éste parece ser uno de ellos».

25 No falta quien defiende que nuestro sistema es derogatorio o de retroactividad ex nunc. Resume los argumentos de ambas posiciones Pelegrí Girón (1988: 3536).

26 García de Enterría (1989: 12), con referencia a la STC 45/1989.

27 En este sentido, Sospedra Navas (2011: 212), que se detiene, en especial en el supuesto de procesos fenecidos por cosa juzgada donde se aplicó una ley declarada posteriormente inconstitucional, con cita de diversas sentencias de la Sala 3. ${ }^{a}$ del TS. Sobre la responsabilidad patrimonial del Estado legislador ante la declaración de inconstitucionalidad de las leyes discurren igualmente, Ahumada Ruíz (2001: 301-350) y 
rán adaptar a la solución del caso concreto los criterios rectores decantados a partir de la jurisprudencia constitucional ${ }^{28}$.

\section{CONFLICTOS DE COMPETENCIA. DIFERENTES SOLUCIONES SEGÚN LOS ACTOS O DISPOSICIONES VICIADOS DE INCOMPETENCIA HAYAN AGOTADO O NO SUS EFECTOS}

Las primeras sentencias mediante las cuales el TC modula el alcance temporal de la declaración de nulidad pertenecen al ámbito de los conflictos constitucionales de competencia entre el Estado y las comunidades autónomas, o de estas entre sí. Son las SSTC 65/1984, de 23 de mayo (RTC $1984 / 65$ ) y 96/1984, de 19 de octubre (RTC 1984/96) ${ }^{29}$. En este contexto, el art. 66 LOTC admite de modo expreso que el TC pueda «disponer lo que fuera procedente respecto de las situaciones de hecho o de derecho creadas al amparo» de la disposición, resolución o acto viciados de incompetencia.

La primera de las sentencias versa sobre el nombramiento de varios registradores de la propiedad para ocupar plazas situadas en el ámbito territorial de la CA de Cataluña, efectuado por sendas resoluciones de la Dirección General de los Registros y del Notariado (DGRN). El TC afirma la competencia de la Generalitat para llevar a cabo el acto formal del nombramiento y, por tanto, la incompetencia, a tal efecto, de la DGRN. En consecuencia, declara nulas las resoluciones conflictivas. En el FJ 3 recuerda la norma del art. 66 LOTC $y$, en ejercicio de la legitimación que le confiere, señala: «En el presente caso, el equilibrio de los intereses en juego aconseja que las situaciones creadas no se destruyan en mayor medida de la que exija la competencia reconocida a la Generalidad. Por lo que se refiere a la situación jurídica de los registradores afectados, dicho equilibrio, dado el carácter de la competencia estatutaria y el régimen de provisión de vacantes, se logra manteniendo dicha situación, condicionada a la ulterior decisión que la Generalidad de Cataluña adopte en el ejercicio de su competencia». En consecuencia, el TC decide mantener en su cargo a los citados Registradores hasta que las plazas sean cubiertas definitivamente por los mismos mediante acto de nombramiento formal dictado, ahora

Ruiz López (2013: 66-95). Este, tras destacar que el supuesto de las leyes declaradas inconstitucionales es el que mayor atención ha merecido por parte de la doctrina y la jurisprudencia en relación con la responsabilidad patrimonial del Estado legislador, analiza los supuestos que califica de más emblemáticos.

28 Insiste en la conveniencia de que sea el propio TC el que concrete el alcance temporal de sus sentencias (González Beilfuss, 2000: 92 y ss.).

29 Se detiene en su comentario Alonso García (1989: 256-257). 
sí, por el órgano competente. En su argumentación, el Abogado del Estado había hecho ver los efectos perjudiciales que podrían derivarse para terceros ausentes del proceso de la anulación, sin más, de las resoluciones. Tales perjuicios afectarían «tanto a los cuatro funcionarios ya nombrados como a aquellos que ocuparon los puestos dejados vacantes por éstos con ocasión de su nombramiento, pues no solo quedarían anuladas las tomas de posesión de los cuatro registros catalanes, sino que resultarían además invalidadas las «resultas» o vacantes originadas, su convocatoria y nueva adjudicación, las nuevas resultas y demás situaciones y actos que en consecuencia se produjeron». Con base en ello solicitó que no se anularan las resoluciones y, subsidiariamente, interesó la limitación de las consecuencias de la eventual anulación, «de forma que se protejan situaciones privadas creadas de buena fe» (Antecedente 3. ${ }^{\circ}$ ). El TC atiende este último alegato y lo combina con un criterio de conservación de la situación generada en la medida de lo posible, medida que viene determinada por un límite: la necesidad de dar satisfacción al ejercicio de la competencia vulnerada.

La segunda de las sentencias citadas (STC 96/1984) trata sobre la competencia del Gobierno vasco para autorizar el folleto de una emisión de obligaciones de "Refinería de Petróleos del Norte, S. A.» y establecer la fecha de su lanzamiento. El recurso se estima parcialmente, solo en cuanto a la incompetencia para fijar la fecha del lanzamiento, declarando la nulidad, en lo referente a este aspecto, de la Orden controvertida. Pero el alcance de la nulidad, de nuevo, se matiza. En el propio fallo, la sentencia añade: «sin que ello implique alteración alguna respecto de las situaciones de hecho o de derecho creadas al amparo de la misma». Este inciso se sustenta en la argumentación ofrecida en el FJ 8: «La necesidad siempre presente de procurar conservar la eficacia jurídica de aquellos actos cuya anulación afectaría a legítimos derechos de terceros generados en su día por la presunción de legalidad de los mismos conduce en este caso, en aplicación del art. 66 de la LOTC, a que la declaración de nulidad no implique alteración alguna de las situaciones de hecho o de derecho que hayan podido crearse al amparo de la Orden» controvertida.

En definitiva, en las dos sentencias reseñadas se mantienen las situaciones de hecho creadas al amparo de los actos anulados. Se apela, para sustentar esta decisión, a la habilitación expresa del art. 66 LOTC, a la presunción de legalidad de los actos que luego se declaran nulos y a la confianza en esta de los sujetos que adquirieron derechos (que el TC califica de «legítimos») con base en ellos - argumentos que apuntan, en última instancia, al principio de seguridad jurídica-. Aunque no se utiliza la expresión situaciones consolidadas, un concepto indeterminado por demás, la idea, en sustancia, es la misma que después se hará jugar en otros pronunciamientos que la emplean. Por otra parte, se vislumbra en estas sentencias un principio de conservación de la situación 
creada al amparo del acto viciado de incompetencia, para tutelar los intereses de sujetos de buena fe, que encuentra, como digo, su límite en la exigencia de ineludible satisfacción de la competencia vulnerada. Al margen de la aplicación al caso concreto que hacen de este criterio, queda sobre el tapete una importante cuestión dogmática con indudables consecuencias prácticas: si pudiera llegar a establecerse la aplicación por la jurisprudencia constitucional de un supuesto principio rector de conservación de la situación creada por actos o normas declarados nulos por el TC, habría que analizar hasta qué punto estamos ante un principio contrario a la concepción de la eficacia retroactiva de la declaración de nulidad como regla general de la que los matices a esta retroactividad constituirían solo excepciones, como tales, de interpretación restrictiva. Quizá se trate de dos principios situados en el mismo plano cuyo equilibrio deba establecerse a la vista del caso concreto sin que uno prevalezca de modo absoluto sobre el otro o, si se prefiere, sin que exista entre ellos una relación de jerarquía.

En el marco de los conflictos de competencia, han seguido a las anteriores numerosísimas sentencias ${ }^{30}$, que se suceden en un goteo constante hasta la actualidad. La mayoría se refieren a normas que regulaban la concesión de subvenciones en distintos ámbitos. Mediante ellas, el TC ha consolidado una doctrina que puede calificarse de tradicional (así lo hace el propio TC en la STC 225/2012). En su virtud, se distingue entre aquellos supuestos en que la disposición viciada de incompetencia ha agotado ya sus efectos (por ejemplo, regulaba la concesión de determinadas subvenciones para una anualidad que ya ha transcurrido, sin que puedan solicitarse nuevas ayudas cubiertas por la norma); y aquellos otros en que tal disposición todavía sería susceptible

30 Entre ellas, las SSTC 24/1985, de 21 de febrero (RTC 1985/24); 48/1985, de 28 de marzo (RTC 1985/48); 75/1989, de 21 de abril (RTC 1989/75); 190/2000, de 13 de julio (RTC 2000/190); 234/2000, de 3 de octubre (RTC 2000/234); 136/2009, de 15 de junio (RTC 2009/136); 138/2009, de 15 de junio (RTC 2009/138); 200/2009, de 28 de septiembre (RTC 2009/138); 156/2011, de 18 de octubre (RTC 2011/156); 38/2012, de 26 de marzo (RTC 2012/38); 73/2012, de 16 de abril (RTC 2012/73); 77/2012, de 16 de abril (RTC 2012/77); 89/2012, de 7 de mayo (RTC 2012/89); 225/2012, de 29 de noviembre (RTC 2012/225); 243/2012, de 17 de diciembre (RTC 2012/243); 9/2017, de 19 de enero (RTC 2017/9). Esta da un toque de atención al Gobierno central que de modo recalcitrante había dictado en los años previos normas equivalentes a las impugnadas, objeto también de conflictos de competencia, apreciándose en todos los casos lesión de las competencias autonómicas de Cataluña. 
de seguir produciendo efectos de no declararse nula (por ejemplo, pretendía ordenar el marco básico para la concesión de subvenciones en sucesivas anualidades) ${ }^{31}$.

En la primera hipótesis (disposición cuyos efectos ya se han agotado), la pretensión del recurrente queda «satisfecha mediante la declaración de la titularidad de la competencia controvertida sin necesidad de que haya de procederse a la anulación de los preceptos correspondientes ${ }^{32}$. Obsérvese que, en este caso, se acoge un principio de conservación que va más allá del mero mantenimiento de situaciones consolidadas al amparo del precepto viciado de incompetencia, pues no se trata solo de conservar los efectos de este (las situaciones creadas bajo su cobertura), sino el precepto mismo del que se afirma su validez o, lo que es igual, no se declara su nulidad. Tal solución se sustenta en la conveniencia de evitar los perjuicios a particulares de buena fe y en tratarse de una disposición cuyos efectos se han agotado ya. Esta última parece ser la consideración determinante para que le TC opte por preservar su validez y no se limite a atemperar los efectos retroactivos de una eventual declaración de nulidad que decide, insisto, no pronunciar. Sea como sea, las consecuencias prácticas de no anular o anular, pero mantener los efectos del acto, que ya los ha agotado, son los mismos ${ }^{33}$.

31 Cabe destacar cómo esta distinción guarda coherencia con la filosofía a que responde la Disposición Transitoria Segunda LOTC en cuanto que solo posibilita la impugnación de leyes, disposiciones, resoluciones o actos anteriores a la constitución del TC que no hubieran agotado sus efectos, vedando la de aquellos que ya los hubiesen agotado.

32 La STC 75/1989, de 21 de abril, resulta paradigmática. La declaración de inconstitucionalidad de las órdenes ministeriales litigiosas - cuyo objeto era convocar, para los respectivos ejercicios presupuestarios, concursos para conceder ayudas a fondo perdido a ciertas actividades privadas de carácter turístico - no lleva al TC a declarar su nulidad: "Como la propia Junta de Galicia pone de relieve, la anulación de las Órdenes impugnadas podría suponer perjuicios, también en Galicia, a quienes hubiesen obtenido subvenciones en virtud de las Ordenes objeto de los presentes conflictos. Por otro lado, estas Órdenes se refieren a ejercicios económicos ya cerrados y que han agotado sus efectos. Dadas las anteriores circunstancias, la pretensión de la Junta de Galicia puede estimarse satisfecha mediante la declaración de la titularidad de la competencia controvertida, sin necesidad de anular las correspondientes Órdenes ni menos todavía las subvenciones ya concedidas al amparo de las mismas».

33 Cabría preguntarse cuál es la solución técnica más correcta. A favor de declarar la nulidad conservando la eficacia de los actos pasados en ejercicio de la facultad de moderación que concede al TC el art. 66 LOTC, se pronuncia Alonso García (1989: 258-259) al hilo de la STC 75/1989. 
En el segundo supuesto (efectos no agotados), en cambio, el TC no se limita a manifestar la titularidad de la competencia discutida, sino que declara la nulidad de pleno derecho de los preceptos viciados de incompetencia para evitar que sigan aplicándose en lo sucesivo (pro futuro). Pero mantiene la eficacia jurídica de las resoluciones que aplicaron en el pasado la disposición conflictiva (las subvenciones ya concedidas), con el fin de «conservar la eficacia jurídica de aquellos actos cuya anulación afectaría a legítimos derechos de terceros generados en su día por la presunción de legalidad» de la disposición impugnada. De este modo, con base en el art. 66 LOTC, se respetan las que el TC considera como situaciones consolidadas ${ }^{34}$.

Todas las sentencias anteriores tienen un rasgo en común: se refieren a actos o disposiciones del ejecutivo sin fuerza de ley en el marco de conflictos de competencia. Pero la doctrina que establecen ha influido, como veremos, en sentencias posteriores que resuelven recursos o cuestiones de inconstitucionalidad con base en problemas competenciales, aunque en este último ámbito falta una norma expresa que habilite al TC para matizar la eficacia temporal de su fallo.

34 Es el caso de la STC 173/2012, relativa a una orden que establecía las bases reguladoras de determinadas subvenciones. El TC aprecia que la disposición impugnada no había agotado todos sus efectos, ya que pretendía establecer el marco de referencia para las sucesivas convocatorias anuales de las ayudas previstas, dictándose, pues, con vocación de permanencia. Por ello, no solo declara la titularidad de la competencia discutida, sino también la nulidad de pleno derecho de los preceptos impugnados para evitar que sean aplicados en sucesivos ejercicios presupuestarios. Hecho esto, entra a concretar los efectos de esta nulidad sobre aquellas disposiciones dictadas, en aplicación de la impugnada, para ordenar la concesión de las subvenciones de referencia en un período temporal limitado (una anualidad o ejercicio presupuestario). Respecto de estas señala que «la necesidad siempre presente de procurar conservar la eficacia jurídica de aquellos actos cuya anulación afectaría a legítimos derechos de terceros generados en su día por la presunción de legalidad de los mismos conduce en este caso, en aplicación del ya citado art. 66 LOTC, a que la declaración de nulidad antes apreciada no implique la de las resoluciones respecto de las cuales ha transcurrido ya el plazo máximo para dictar y notificar la resolución concediendo o denegando las ayudas cuestionadas, ni tampoco proceda, por tanto, pronunciamiento alguno respecto a la exigencia de territorialización de las mismas. No sucede lo mismo, sin embargo, respecto a las subvenciones en las que los efectos de la convocatoria no se han agotado, las cuales carecen igualmente de eficacia en aquellos aspectos que incidan en las reconocidas competencias autonómicas de gestión en relación con las ayudas a las que en la misma se hagan referencia». En igual sentido entre otras, las SSTC 200/2009, 73/2012, 77/2012 o 243/2012. 


\section{RECURSO/CUESTIÓN DE INCONSTITUCIONALIDAD. EL PUNTO DE INFLEXIÓN: LA STC 45/1989}

Ya en el ámbito del recurso/cuestión de inconstitucionalidad y, por tanto, con referencia a normas con rango de ley, la primera sentencia que pone en entredicho con claridad el vínculo inquebrantable entre declaración de inconstitucionalidad y nulidad, y entre nulidad y eficacia retroactiva es la STC 45/1989, de 20 de febrero (RTC 1989/45), dictada en relación con determinados preceptos de la Ley 44/1978, de 8 de septiembre, de Normas Reguladoras del Impuesto sobre la Renta de las Personas Físicas. En ella se enjuicia, en esencia, el sistema de declaración conjunta que se impone a las personas casadas ${ }^{35}$. Se trata de una sentencia que en su momento dio pie a numerosos análisis y comentarios doctrinales y que tuvo, incluso, transcendencia mediática ${ }^{36}$. García de Enterría (1989: 5-6) destaca su importancia no solo por su fondo - la inconstitucionalidad que declara-, sino, sobre todo, "por la innovación que ha supuesto en la determinación de los efectos de esa inconstitucionalidad», y afirma que estamos ante "la primera Sentencia de nuestro Tribunal Constitucional que acoge con plena consciencia la doctrina de la llamada por el Tribunal Supremo americano "prospectividad» del fallo (efectos a partir de la fecha de este), frente a la tradición de la «retroactividad» de los efectos de la declaración de inconstitucionalidad de una Ley».

Con anterioridad a esta sentencia, el TC había efectuado una tímida incursión en el camino de la atemperación de los efectos de la nulidad en las SSTC 60/1986, de 20 de mayo (RTC 1986/60), y 26/1987, de 27 de febrero (RTC 1987/26), pero es la STC 45/1989 la que marca con sus argumentos el camino de las posteriores.

Para entender el punto de inflexión que supuso, conviene hacer referencia a la situación previa. Hasta ese momento, la poca claridad de la CE y de

35 El TC declara inconstitucionales los preceptos impugnados no por imponer una declaración conjunta a los cónyuges o establecer su responsabilidad solidaria, sino por la forma de hacerlo: considera discriminatorio el método para determinar la cantidad de la que responden solidariamente los consortes e igualmente inaceptable la regulación prevista para el supuesto de discordia entre ellos, la forma de determinar la base imponible por pura acumulación de las rentas de los miembros de la unidad familiar y el no contemplar posibilidad alguna de sujeción separada al IRPF en los casos en que la sujeción conjunta es imposible o carece de justificación.

36 García de Enterría (1989: 5) da noticia de la aparición de numerosos comentarios periodísticos. Tras ellos vendrían los análisis doctrinales más detenidos. Además del anterior, véanse, entre otros, Alonso García (1989: 225-268), Montoro Chiner (1990: 223-235) o Caamaño Anido (1997: 167-180). 
la LOTC habían dado lugar a interpretaciones divergentes acerca del alcance en el tiempo de la declaración de inconstitucionalidad. En materia fiscal, ante pronunciamientos en los que el TC declaraba la nulidad de ciertos preceptos por inconstitucionales sin precisar el alcance temporal de la nulidad, el Gobierno había entendido, llegado el momento de ejecutar las sentencias, que los efectos eran ex tunc. Así ocurrió con la STC 179/1985, de 19 de diciembre (RTC 1985/179), en que la disposición declarada inconstitucional había permitido a los ayuntamientos imponer recargos sobre el IRPF; y en la STC 19/1987, de 17 de febrero (RTC 1987/19) en que, con base en la norma declarada nula, los ayuntamientos habían podido fijar libremente los tipos de la Contribución Territorial. Tras ellas el Gobierno aprobó sendos Reales Decretos para articular la devolución de los recargos impositivos y contribuciones territoriales indebidamente cobrados por aplicación de los preceptos inconstitucionales ${ }^{37}$.

Sobre una materia diferente a la fiscal, dentro del ámbito administrativo, se dictó, pocos días después de la última de las citadas, la STC 26/1987, de 27 de febrero (RTC 1987/26), que resolvió un recurso de inconstitucionalidad contra determinados preceptos de la Ley Orgánica 11/1983, de 25 de agosto, de Reforma Universitaria. En esta sentencia (FJ 12, 5, c) sí que hay un pronunciamiento sobre el alcance temporal de la declaración de inconstitucionalidad con referencia a un aspecto determinado de los que debía valorar el Tribunal: la composición de las Comisiones que han de resolver los concursos de méritos «entre profesores del Cuerpo a que corresponda la vacante», es decir, entre quienes perteneciendo ya a uno de los Cuerpos previstos en el art. 33 (catedráticos o profesores titulares de Universidad), pretendan su traslado a una plaza de otra Universidad. El TC declara que la «apreciación de inconstitucionalidad no supone anulación o invalidación de las situaciones creadas al amparo del precepto, ya que su inconstitucionalidad no resulta de la composición concreta de las Comisiones allí previstas, sino del carácter de imposición forzosa de la misma a las Universidades, excluyendo su capacidad reguladora al respecto» ${ }^{38}$.

37 En el primer caso no llegó a plantearse incidente de ejecución de sentencia pidiendo aclaración al TC sobre el grado de afección de las situaciones producidas al amparo de la norma mientras esta estuvo vigente (cfr. art. 92 LOTC). En el segundo, aunque se utilizó esta vía, resultó improductiva, al inadmitirse el incidente.

38 Esta sentencia —dice Pelegrí Girón (1988: 3554)— «se dicta en un momento en el que la preocupación por resolver la eficacia retroactiva de las sentencias de procedimiento de inconstitucionalidad declaratorias de la inconstitucionalidad y nulidad de las leyes, está en su punto más álgido. Consciente de la preocupación de la Administración Pública encargada de la ejecución de las sentencias del Tribunal respecto a la 
Dos años después se dicta la STC 45/1989, de 20 de febrero, que se ha convertido en una especie de leading case, a la que seguirán numerosos pronunciamientos que han ido conformando la doctrina - no cerrada, por su carácter casuístico- del TC sobre la materia. En esta sentencia, el TC, atendiendo la petición del abogado del Estado ${ }^{39}$, dedica el largo FJ 11 a precisar el alcance concreto de la declaración de inconstitucionalidad en el supuesto enjuiciado, en términos que después aparecen reiterados en otras muchas.

En lo que toca a los efectos, hemos de comenzar por recordar que, de acuerdo con lo dispuesto en la Ley Orgánica de este Tribunal (art. 39.1), las disposiciones consideradas inconstitucionales han de ser declaradas nulas, declaración que tiene efectos generales a partir de su publicación en el «Boletín Oficial del Estado» (art. 38.1 LOTC) y que en cuanto comporta la inmediata y definitiva expulsión del ordenamiento de los preceptos afectados (STC 19/1987, fundamento jurídico 6. ${ }^{\circ}$ ) impide la aplicación de los mismos desde el momento antes indicado, pues la Ley Orgánica no faculta a este Tribunal, a diferencia de lo que en algún otro sistema ocurre, para aplazar o diferir el momento de efectividad de la nulidad.

La consecuencia es que se aplica la normativa que quedó excluida provisionalmente con la entrada en vigor de la ley que se anula. Sin embargo, la sentencia no se detiene en esa declaración conservadora y añade que «[n]i esa vinculación entre inconstitucionalidad y nulidad es, sin embargo, siempre necesaria, ni los efectos de la nulidad en lo que toca al pasado vienen defini-

anulación de los efectos producidos por la ley inconstitucional desde su entrada en vigor hasta su declaración de inconstitucionalidad, el magistrado ponente decide pronunciarse expresamente a favor de la validez de estas situaciones nacidas al amparo de un concurso de méritos cuyo procedimiento de selección luego es declarado inconstitucional». Véase, también, Málvarez Pascual (1988: 55 y ss.).

39 Este solicitó que se declarase que los preceptos impugnados no eran nulos; y subsidiariamente que el TC precisara el alcance del fallo eventualmente invalidatorio. En sus alegaciones subrayó que el límite constituido por la cosa juzgada del art. 40.1 LOTC no necesita ser interpretado como si «constituyera la excepción a una imaginaria regla, que sería la del máximo alcance invalidatorio de la sentencia de inconstitucionalidad en su dimensión temporal (efectos máximos ex tunc o «retroactivos»). Más bien al contrario: si consideramos al art. 40.1 de la LOTC informado por el principio constitucional de seguridad jurídica, habrá que entender que los procesos fenecidos por Sentencia firme son el caso más eminente y claro, pero no el único. Dicho de otro modo: la mención de la Sentencia firme en el art. 40.1 no supone que toda Sentencia de inconstitucionalidad haya de tener por necesario efecto la eliminación radical de todas las situaciones jurídicas preexistentes que no estén declaradas en Sentencia con autoridad de cosa juzgada, por agotadas o jurídicamente consolidadas que estén». 
dos por la Ley, que deja a este Tribunal la tarea de precisar su alcance en cada caso, dado que la categoría de la nulidad no tiene el mismo contenido en los distintos sectores del ordenamiento", aunque no cita el precepto legal que encomienda esta labor al TC. La única norma que lo hace de modo expreso es el transcrito art. 66 LOTC, relativo a los conflictos de competencia. Pero aun prescindiendo de este precepto puede entenderse que el TC está legitimado para concretar el alcance de la nulidad con base en la compleja función que le corresponde en nuestro sistema y en la flexibilidad que cabe predicar de la esquiva categoría de la nulidad.

La doctrina que establece la STC 45/1989 al precisar los efectos de la declaración de inconstitucionalidad de la ley litigiosa, confirmada después — como digo- en numerosas sentencias, puede sintetizarse en los siguientes puntos:

1. Cuando la razón de la inconstitucionalidad del precepto no reside en determinación textual alguna de este, sino en su omisión, quiebra la conexión entre inconstitucionalidad y nulidad, sin que deba anularse la disposición.

El TC, en la sentencia de referencia, considera que un sistema de tributación conjunta de los miembros de la unidad familiar no es en sí mismo inconstitucional, siempre que se abra la posibilidad de tributación individual en aquellos casos en que la aplicación de la tributación conjunta resulte imposible o produzca efectos discriminatorios, en cuyo supuesto no sería admisible imponerla. Al no brindar el art. 4.2 de la Ley litigiosa esta posibilidad, es declarado inconstitucional. Pero tal declaración no va acompañada de la de nulidad, en cuanto la aplicación de la disposición es lícita en todas aquellas hipótesis — que son la mayoría - en que no se dan las circunstancias que exigen conceder la posibilidad de tributación individual. A partir de ahí, el legislador debe efectuar las modificaciones necesarias en el sistema para contemplar la peculiaridad de los casos que exigen el tratamiento diferencial hasta entonces omitido.

2. Cuando las disposiciones declaradas inconstitucionales forman parte de un sistema legal cuya plena acomodación a la CE no puede alcanzarse mediante la sola anulación de aquellas reglas, ha de entrar en juego la acción del legislador, que debe efectuar las modificaciones o adaptaciones pertinentes en el régimen legal de que se trate en ejercicio de su propia libertad de configuración normativa, que no puede ser desconocida ni sustituida por el TC. La sanción de nulidad de los preceptos inconstitucionales es una medida — dice el TC— «estrictamente negativa». Apli- 
cando esta idea al caso de autos, el TC concluye que no está legitimado para reordenar el régimen del IRPF en términos compatibles con la Constitución. Esta es misión del legislador.

3. Declarada la nulidad de una disposición inconstitucional, se establece que son situaciones consolidadas no susceptibles de ser revisadas no solo aquellas decididas mediante sentencia con fuerza de cosa juzgada (art. 40.1 LOTC), sino, también, por exigencia del principio de seguridad jurídica (art. 9.3 CE), las establecidas mediante actuaciones administrativas firmes. Entiende el TC que la conclusión contraria entrañaría un inaceptable trato de disfavor para quien recurrió, sin éxito, ante los Tribunales en contraste con el trato recibido por quien no instó en tiempo la revisión del acto de aplicación de las disposiciones hoy declaradas inconstitucionales ${ }^{40}$.

En numerosísimas sentencias posteriores, muchas con llamada directa a la STC 45/1989, se reitera esta idea, de modo que solo serán revisables las situaciones que, a la fecha de la publicación de la sentencia que declara la inconstitucionalidad del precepto en que se apoyan, no hayan adquirido firmeza por haber sido impugnadas en tiempo y forma y no haber recaído todavía una resolución administrativa o judicial firme sobre estas. En caso contrario, la situación se considera consolidada (por ejemplo, la nulidad del precepto en que se sustentó el pago de impuestos no puede justificar una pretensión de devolución de ingresos indebidos cuando la situación administrativa ha devenido firme $)^{41}$.

40 En cualquier caso, no queda claro si la extensión de la limitación del art. 40.1 LOTC a las situaciones administrativas consolidadas es automática o debe decidirse en cada caso atendiendo a las circunstancias y a los bienes y principios jurídicos en juego. Se inclina por lo último Gómez Montoro (2001: 619), quien, además, denuncia la insuficiencia del argumento de la seguridad jurídica, por sí mismo, para justificar la inamovilidad de las situaciones administrativas firmes, no susceptibles de recurso, pues "también afecta a la seguridad jurídica que la posibilidad de recurrir los actos adoptados en aplicación de la ley inconstitucional dependa de circunstancias tales como la mayor o menor diligencia de la Administración en la resolución de los expedientes y los posibles recursos a que dichos actos hubieran dado lugar, o la mayor o menor rapidez del TC en resolver los recursos y cuestiones de inconstitucionalidad».

41 SSTC 146/1994, de 12 de mayo (RTC 1994/146); 179/1994, de 16 de junio (RTC 1994/179); 185/1995, de 14 de diciembre (RTC 1995/185); 180/2000, de 26 de junio (RTC 2000/180); 194/2000, de 19 de julio (RTC 2000/194); 289/2000, de 30 de noviembre (RTC 2000/289); 234/2001, de 13 de diciembre (RTC 2001/234); 
A partir de la idea anterior se concreta el alcance de la nulidad en el caso de autos en el sentido de que no cabe solicitar la restitución de los pagos hechos en virtud de autoliquidaciones o liquidaciones provisionales o definitivas acordadas por la Administración con base en la normativa declarada inconstitucional. En cambio, el impuesto devengado en el ejercicio 1988 ya no puede ser liquidado y exigido conforme con esta (todavía no lo había sido al publicarse la sentencia).

\section{EL ALCANCE TEMPORAL DE LA DECLARACIÓN DE INCONSTITUCIONALIDAD EN LA JURISPRUDENCIA CONSTITUCIONAL POSTERIOR A LA STC 45/1989. GRUPOS DE CASOS}

La STC 45/1989 marcó un punto de camino sin retorno. Desde entonces, el TC ha matizado en diversos sentidos la nulidad derivada de la declaración de inconstitucionalidad de las leyes o normas con fuerza de ley. A partir de sus pronunciamientos pueden rastrearse ciertos patrones que permiten una clasificación de las sentencias en los siguientes grupos ${ }^{42}$.

a. Casos de mera inconstitucionalidad sin nulidad. Un primer conjunto de sentencias se halla integrado por aquellas en las que, pese a declararse la

54/2002, de 27 de febrero (RTC 2002/54); 3/2003, de 16 de enero (RTC 2003/3); 48/2004, de 25 de marzo (RTC 2004/48); 176/2011, de 8 de noviembre (RTC 2011/176); 196/2012, de 31 de octubre (RTC 2012/196); 9/2013, de 28 de enero (RTC 2013/9); 60/2013, de 13 de marzo (RTC 2013/60); 86/2013, de 11 de abril (RTC 2013/86); 104/2013, de 25 de abril (RTC 2013/104); 206/2013, de 5 de diciembre (RTC 2013/206); 219/2013, de 19 de diciembre (RTC 2013/219); 40/2014, de 11 de marzo (RTC 2014/40); 22/2015, de 16 de febrero (RTC 2015/22); 60/2015, de 18 de marzo (RTC 2015/60); o la reciente STC 140/2016, de 21 de julio (RTC 2016/149), sobre las tasas judiciales. En relación con los efectos temporales de la declaración de inconstitucionalidad contenida en esta última sentencia, subraya García Moreno (2016: 15-16) cómo el TC, al establecer la prospectividad de la declaración de inconstitucionalidad, ha querido evitar, como en otros casos similares, cualquier problema financiero a las arcas públicas, "convalidando» todos los tributos pagados durante la vigencia del precepto inconstitucional siempre que el contribuyente no hubiere impugnado el pago de la tasa. En la fundamentación jurídica de la sentencia, se remarca la coherencia de esta solución con la razón de la inconstitucionalidad: el acceso a la tutela judicial efectiva, dado que el contribuyente que ha podido satisfacer la tasa y acceder a esta tutela no ha visto vulnerado tal derecho.

42 Pueden encontrarse ensayos de sistematización de las sentencias del TC en esta materia, en Gómez Montoro (2001: 587 y ss.), Gómez Corona (2009: 263-288) o De la Cueva Aleu (2010: 439 y ss.). 
inconstitucionalidad, no se declara la nulidad ${ }^{43}$. De la doctrina que contienen se deducen varias conclusiones:

1.' El TC, pese a no existir una norma habilitante clara de derecho positivo, se considera legitimado para establecer el alcance temporal de la declaración de inconstitucionalidad, incluida la posibilidad de no declarar nula la disposición inconstitucional, que ya había sido avanzada y parcialmente aplicada en la STC 45/1989.

2. El fundamento de la decisión de no declarar la nulidad del acto o precepto inconstitucional depende de la razón que ha conducido a la declaración de inconstitucionalidad.

En un primer bloque de sentencias, tal decisión se basa en razones de seguridad jurídica conectadas con la conveniencia de evitar graves perjuicios a los intereses generales y/o particulares. Se trata de supuestos en que los preceptos inconstitucionales han agotado los efectos que podían producir de modo que, respecto de ellos, solo cabe identificar situaciones ya consolidadas en el momento de publicarse la sentencia. Es el caso, por ejemplo, de las SSTC 13/1992, de 6 de febrero (RTC 1992/13) ${ }^{44}$, y 95/2002, de 25 de abril (RTC

43 Así, entre otras, las SSTC 13/1992, de 6 de febrero (RTC 1992/13); 222/1992, de 11 de diciembre (RTC 1992/222); 16/1996, de 1 de febrero (RTC 1996/16); 68/1996, de 4 de abril (RTC 1996/68); 95/2002, de 25 de abril (RTC 2002/95); 138/2005, de 26 de mayo (RTC 2005/138); 273/2005, de 27 de octubre (RTC 2005/273); 52/2006, de 16 de febrero (RTC 2006/52); 120/2010, de 24 de noviembre (RTC 2010/120); 131/2010, de 2 de diciembre (RTC 2010/131); 132/2010, de 2 de diciembre (RTC 2010/132). Sobre la insuficiencia del binomio inconstitucionalidad/nulidad, efectúan interesantes consideraciones González Beilfuss (2000: 31 y ss.) y Gómez Montoro (2001: 588 y ss.).

44 El FJ 17 precisa el alcance concreto que debe atribuirse a la declaración de inconstitucionalidad de determinadas partidas presupuestarias. La anulación de estas "podría suponer graves perjuicios y perturbaciones, también en Cataluña, a los intereses generales, afectando a situaciones jurídicas consolidadas, y particularmente a la política económica y financiera del Estado. Por otra parte, [...] se refieren a ejercicios económicos ya cerrados y que han agotado sus efectos. Dadas las anteriores circunstancias y como ya se hiciera en la STC 75/1989, la pretensión de la Generalidad de Cataluña puede estimarse satisfecha mediante la declaración de inconstitucionalidad de aquellas partidas presupuestarias que han invadido sus competencias, sin necesidad de anular los citados preceptos presupuestarios ni menos todavía las subvenciones ya concedidas al amparo de los mismos. Por todo ello, el alcance de los efectos generales de la decla- 
2002/95). Entre los intereses dignos de tutela que se consideran destacan, en muchos casos, las repercusiones económicas que podría tener la declaración de nulidad resultando desproporcionadamente gravosa para las arcas públicas, lo que afectaría de modo significativo «a la política económica y financiera del Estado» (en palabras de la STC 1992/13).

Estas consideraciones económicas subyacen, de modo más o menos confesado, en muchas sentencias que versan sobre impuestos o subvenciones en relación sobre todo con normas de aplicación masiva. En ellas, los efectos de la declaración de inconstitucionalidad, según se matice más o menos su alcance en el tiempo, pueden suponer la obligación de devolver ingentes cantidades de dinero a costa del Tesoro Público. Tales consecuencias se evitan por la vía de romper el binomio inconstitucionalidad/nulidad (supuesto al que ahora me refiero), o por la vía de declarar la nulidad, pero limitando su alcance retroactivo (hipótesis sobre la que reflexionaré después). El derecho comparado muestra que se trata de una constante en no pocos países, especialmente en Alemania, cuya influencia en esta materia es indudable, y puede vislumbrarse también en la práctica del TJUE. La primera pregunta que se plantea al intérprete es la relativa a la justificación jurídica de tal proceder, hasta qué punto es lícito que este tipo de razones pragmáticas determinen el mantenimiento de situaciones inconstitucionales ${ }^{45}$. La respuesta debe buscarse en el necesario equilibrio,

ración de inconstitucionalidad acordada se limita a los futuros ejercicios presupuestarios posteriores a la fecha de publicación de esta Sentencia».

45 González Beilfusss (2000: 76 y ss.) reconoce que en la práctica jurisprudencial «las posibles consecuencias económicas de las sentencias no acostumbran a resultar indiferentes para los Tribunales Constitucionales. Así, por ejemplo, en sede de interpretación constitucional es habitual reconocer que el legislador dispone de un mayor margen de actuación en aquellos ámbitos en que una sentencia estimatoria puede alterar el equilibrio económico-financiero de un sistema». Se remite, para ilustrarlo, a las SSTC 184/1993, 268/1993 o 38/1995, relativas al proceso de equiparación de los distintos regímenes que integran el sistema de la Seguridad Social. Señala cómo en la jurisprudencia alemana el impacto económico de la sentencia no ha conducido simplemente a limitar el alcance retroactivo de la nulidad, sino que, en algún caso, ha llegado al extremo de afectar al propio carácter estimatorio o desestimatorio de la sentencia (cita la sentencia 21, 12, relativa al antiguo impuesto en cascada sobre las ventas - Umsatzsteuer - cuya manifiesta inconstitucionalidad no se plasmó en un fallo estimatorio debido, entre otras cuestiones, a que del mismo dependían el cuarenta y cinco por ciento de los ingresos tributarios federales)». En el TC español, algunos magistrados han llegado a abogar, en sus votos particulares, por un fallo desestimatorio con base en las consecuencias económicas de la sentencia (así, Arozamena Sierra y Pera Verdaguer en el voto particular a la STC 103/1983, sobre régimen general de las 
que respete el principio de proporcionalidad, entre los diferentes principios y derechos constitucionales afectados. A la luz de este criterio, la valoración de las repercusiones económicas de la sentencia de inconstitucionalidad según los efectos más o menos retroactivos de los que se la dote podría conectarse con el principio de seguridad jurídica o con la tutela de los distintos bienes jurídicos de interés general a los que sirve el gasto programado en unos presupuestos públicos que quedarán afectados por la sentencia. Como algún autor ha señalado puede incluso lesionarse la competencia de las Cortes Generales para decidir la distribución del gasto público, que resultará condicionada por la sentencia en casos de devolución masiva de notables cantidades de dinero, como puede ocurrir con algunas normas tributarias declaradas inconstitucionales ${ }^{46}$.

En un segundo bloque, la decisión se fundamenta en obedecer la inconstitucionalidad no a razones de fondo, sino formales: en concreto, no haberse respetado el rango normativo impuesto en la materia de referencia. Así, en las SSTC 131/2010, de 2 de diciembre (RTC 2010/131), y 132/2010, de 2 de diciembre (RTC 2010/132), en que se había regulado mediante ley ordinaria materia sujeta a reserva de ley orgánica. Estas dos sentencias resolvieron sendas cuestiones de inconstitucionalidad planteadas por el mismo Juzgado de Primera Instancia, la primera contra el art. 211.I CC y la DF $23 .^{\text {a }}$ de la LO 1/1996, de 15 de enero, de protección jurídica del menor, y la segunda, contra el art. 763.I y II LEC. Tanto la norma del CC como la de la LEC regulaban la misma medida de internamiento forzoso de las personas que padezcan trastornos psíquicos (el CC lo hacía antes de que entrara en vigor la LEC/2000) ${ }^{47}$.

pensiones de viudedad). El autor concluye con una interesante reflexión: no estamos ante una cuestión de mera sensibilidad política de los tribunales constitucionales, sino que el problema guarda estrecha relación con un bien jurídico a considerar, como es la competencia de las Cortes Generales para decidir la distribución del gasto público (cita los arts. 66.2, 134.1 y 6, 133.4 y 134.5 CE). Refuerza su argumentación con algunos apuntes de derecho comparado. Sobre la consideración del impacto que la nulidad sin matices puede acarrear en el sistema financiero del Estado y su influencia en la gradación de los efectos temporales de la declaración de inconstitucionalidad reflexionan también Balaguer Callejón (2001: 165) y González-Varas Ibáñez (2009: 363 y ss.), que destaca la importancia del argumento en el derecho alemán.

46 En este sentido, González Beilfusss (2000: 76 y ss.).

47 La STC 131/2010 señala, con cita de otras anteriores, que «no siempre es necesaria la vinculación entre inconstitucionalidad y nulidad». Tal ocurre en el presente supuesto, pues la declaración de nulidad del art. 211.I CC crearía un indeseable vacío en el ordenamiento jurídico, «máxime teniendo en cuenta que dicho precepto no ha sido cuestionado en su contenido material, esto es, no se ha discutido la pertinencia de la medida de internamiento de las personas incapacitadas por razón de trastorno 
En un tercer bloque de sentencias, de las que constituyen ejemplos las SSTC 222/1992, de 11 de diciembre (RTC 2011/222); 138/2005, de 26 de mayo (RTC 2005/138); 273/2005, de 27 de octubre (RTC 2005/273); 52/2006, de 16 de febrero (RTC 2006/52); y 120/2010, de 24 de noviembre (RTC 2010/120), el motivo de no declarar la nulidad del precepto inconstitucional radica en que tal inconstitucionalidad no deriva de ninguna prescripción textual de la disposición, sino de haber omitido esta algunos supuestos que deberían encontrarse incluidos. Esta doctrina había sido iniciada por la STC 45/1989, como antes hemos visto, se incluyen también en este bloque los casos de discriminación por exclusión tácita de determinadas categorías de sujetos a los que debería haberse aplicado igual régimen que a los contemplados en la regulación. No se trata, por tanto, de suprimir o cancelar alguna de las partes de los preceptos cuestionados, sino, al contrario, de ampliar su objeto, para incluir aquellas hipótesis que han sido excluidas sin justificación ninguna, un objetivo que no se satisface declarando nula la disposición inconstitucional.

psíquico en establecimiento de salud mental mediante autorización judicial, a lo que ha de añadirse que, en realidad, se trata de un precepto ya derogado». Recuerda que, desde la entrada en vigor de la LO 1/1996, de 15 de enero, cuya Disposición Final 12. a dio una nueva redacción al art. 211.I CC, y hasta la publicación de la presente sentencia por la que declaramos la inconstitucionalidad de su calificación legislativa en la Disposición Final 23. ${ }^{a}$ de la citada LO 1/1996 como norma no orgánica "[...] ha mediado un tiempo en el que dicha calificación desplegó plena eficacia, integrándose en su virtud en el ordenamiento aquella norma como una ley ordinaria, lo que hizo posible efectos tales como, precisamente, la derogación posterior del art. 211 en su integridad por una ley desprovista del carácter orgánico, es decir, por la Ley 1/2000, de 7 de enero, de Enjuiciamiento Civil [...] Vigente, pues, como norma ordinaria durante toda su existencia, el párrafo primero del art. 211 del Código Civil, ha de ser declarado inconstitucional, pero no nulo, como antes ya se dijo, por lo que despliega todos sus efectos hasta su derogación por la Ley 1/2000, de 7 de enero, de Enjuiciamiento Civil [...] sin perjuicio de la correspondiente modulación de esos efectos que pudiera resultar de lo establecido en las disposiciones transitorias de dicha ley, cuyo art. 763.1 regula actualmente la medida judicial de internamiento forzoso por razón de trastornos psíquicos, precepto sobre el que este Tribunal ha de pronunciarse al resolver la cuestión de inconstitucionalidad núm. 4542-2001, planteada por el mismo órgano judicial del que procede la presente cuestión» (FJ 6).

La citada cuestión de inconstitucionalidad es, precisamente, la que resuelve la STC 132/2010, que respecto del art. 763.1 LEC establece en el FJ 3 la misma doctrina que la anterior. 
Los casos resueltos en las SSTC 138/2005 y 273/2005 versaban sobre sendas disposiciones de carácter civil: los arts. 136. I CC y 133. I CC, respectivamente (según redacción por Ley 11/1981, de 13 de mayo). En la primera, el TC declaró inconstitucional el art. 136.I CC, en cuanto suponía que el plazo para el ejercicio de la acción de impugnación de la paternidad matrimonial, determinada con base en la presunción de paternidad del marido de la madre (arts. 116 y 117 CC), empezase a correr, aunque el marido ignorase no ser el progenitor biológico del niño inscrito como hijo suyo en el Registro Civil. Consideró que al omitirse la condición del conocimiento de la verdad biológica como componente del dies a quo se vulneraba el derecho a la tutela judicial efectiva en su aspecto de derecho de acceso a la jurisdicción (véase art. 24.1 CE). En el FJ 6 fijó el alcance del fallo apelando a la doctrina de la STC 45/1989 conforme con la cual no es necesaria la vinculación entre inconstitucionalidad y nulidad cuando la razón de la inconstitucionalidad del precepto reside no en determinación textual alguna de este, sino en su omisión: «En el presente caso no procede declarar la nulidad de la regla legal que concede hoy al marido la acción de impugnación de la paternidad legal, resultado éste que, sobre no reparar en nada la inconstitucionalidad apreciada, dañaría, sin razón alguna, a quienes ostentan, en virtud del art. 136 CC, una acción que no merece tacha alguna de inconstitucionalidad. [...] generaría un vacío normativo, sin duda no deseable». Añade: "La inconstitucionalidad apreciada exige que sea el legislador, dentro de la libertad de configuración de que goza, derivada de su posición constitucional y, en última instancia, de su específica legitimidad democrática [...] el que trace de forma precisa, en aras de la seguridad jurídica (art. 9.3 CE) el dies a quo del plazo para el ejercicio de la acción de impugnación de la paternidad matrimonial prevista en el art. 136 CC, dentro de cánones respetuosos con el derecho a la tutela judicial efectiva (art. 24.1 CE)». La STC 273/2005, que declara inconstitucional el art. 133.I CC, en cuanto impide al progenitor no matrimonial la reclamación de la filiación en los casos de inexistencia de posesión de estado, reitera la anterior doctrina (el FJ 9, que precisa el alcance del fallo, es un clon del FJ 6 de la STC $138 / 2005)$.

También sobre materia civil trata la STC 222/1992, de 11 de diciembre (RTC 1992/222), que representa un caso de discriminación normativa por exclusión tácita. Tras declarar inconstitucional por discriminatoria la diferenciación contenida en el art. 58 LAU según redacción entonces vigente, entre el cónyuge supérstite de una unión matrimonial y quien hubiera convivido more uxorio con la persona titular del arrendamiento hasta su fallecimiento, en relación con la facultad de subrogarse en la relación arrendaticia al morir el titular, señala: «Ha de declarar este fallo, desde luego, la inconstitucionalidad sobrevenida de la exclusión enjuiciada, pero no la 
nulidad de la regla legal que concede hoy al «cónyuge» el beneficio de la subrogación, resultado éste que, sobre no reparar en nada la discriminación apreciada, dañaría, sin razón alguna, a quienes ostentan, en virtud del art. 58.1 LAU, un derecho que no merece, claro está, tacha alguna de inconstitucionalidad» (FJ 7).

En opinión del TC, la declaración de nulidad generaría un vacío normativo indeseable que, por una parte, no ofrecería una solución justa o más justa a los perjudicados por la disposición inconstitucional y, por otra, perjudicaría a quienes pueden utilizarla para satisfacer intereses legítimos ${ }^{48}$. Considera más equilibrado mantener vigente la disposición hasta que el legislador, en uso de su poder de configuración del ordenamiento jurídico, dicte las normas oportunas en sustitución de aquella. La solución no es, pues, la declaración de nulidad del precepto inconstitucional, sino la obligada reforma legislativa de este y su mantenimiento en vigor mientras aquella se produce. Sea como sea, en este bloque de sentencias, lo que no llega a aclarar el TC es qué hacer en el ínterin, mientras el legislador no dicte la nueva regulación —y no se le fija plazo para hacerlo- que sustituya a la anterior acomodándose a la $\mathrm{CE}^{49}$.

b. Casos en que se difiere la declaración de nulidad a un momento posterior al de la publicación de la sentencia de inconstitucionalidad. Se trata de procesos en los que se dirimen conflictos competenciales entre el Estado y una comunidad autónoma. El objeto primordial de la sentencia radica en la determinación de la titularidad de la competencia controvertida. El TC considera que, una vez establecida la conclusión fundamental de a

48 González Beilfus (2000: 32 y ss.) profundiza en la inadecuación técnica del binomio inconstitucionalidad-nulidad para hacer frente a las discriminaciones normativas, especialmente evidente en los supuestos de discriminación por exclusión tácita (casos en que los preceptos excluyen tácitamente de su regulación a un determinado colectivo vulnerando el derecho a la igualdad). Al no constituir alternativa viable la desestimación de los recursos, el TC prefiere flexibilizar el alcance de la nulidad (SSTC 116/1987 —amnistía de los profesionales militares de la República- o 142/1990 — pensiones de viudedad-) o, en sentencias posteriores a la STC 45/1989 y quizá influenciado por la práctica del Tribunal Federal alemán, romper el binomio inconstitucionalidad-nulidad (SSTS 222/1992 — subrogación arrendaticia de las parejas de hecho- o 3/1993 — prestaciones a favor de familiares - ).

49 El problema ha sido subrayado por diversos autores. García Vicente (2006: 540), entendió, respecto de la STC 138/2005, que, mientras el legislador no modificase el art. 136.I CC, los tribunales ordinarios deberían computar el plazo desde el conocimiento de la verdad biológica por derivarse tal reconstrucción del precepto de la sentencia del TC (en concreto, de sus FFJJ 4 y 6 ). 
quien corresponde la competencia, aunque se declare inconstitucional la disposición impugnada por emanar de quien carecía de tal, deben evitarse al máximo los posibles perjuicios que esta declaración puede producir en el entramado de bienes, intereses y derechos afectados (por ejemplo, la protección, conservación, restauración y mejora de un espacio o reserva natural en las SSTC 195/1998 y 194/2004 o los intereses vinculados a la defensa de la competencia en la STC 208/99). Si la disposición se declarase nula sin más, se produciría un vacío normativo del que podrían derivarse perjuicios irreparables (vinculados con los intereses generales o con la afectación de situaciones y actuaciones jurídicas consolidadas), que, además, son ajenos e, incluso, abiertamente contrarios a las pretensiones deducidas en el recurso. Piénsese, por ejemplo, en un paraje natural declarado protegido por la disposición que resulta inconstitucional por razones de competencia si se anulase esta, resultaría desamparado mientras el centro de poder competente no dictara las normas oportunas. Estas resoluciones emplean una técnica de exhortación al legislador competente, difiriendo la declaración de nulidad hasta que este adopte medidas, para evitar las consecuencias negativas que activaría una declaración inmediata de nulidad ${ }^{50}$. El propio TC es consciente de que su solución provoca la "persistencia de una situación anómala, en la que las competencias controvertidas pueden seguir siendo ejercitadas por el Estado (en un caso en que correspondian a la comunidad o comunidades autónomas). Esa situación es, desde luego, provisional y, por supuesto, debe acabar cuanto antes. «La lealtad constitucional obliga a todos» (STC 209/1990, FJ 4) y, en este

50 La fórmula procede del derecho austriaco. Destaca las dificultades teóricas y prácticas de esta técnica en nuestro sistema, Rubio Llorente (1988: 37). En sentido crítico, se pronuncia, también, Bocanegra Sierra (1991: 529-532). Tejedor Bielsa (1999: 21-23) subraya el peligro de que, bajo el expediente de la declaración de inconstitucionalidad con nulidad demorada, se dé amparo a una cuestionable competencia normativa universal del Estado, más allá de sus competencias tasadas en la CE, cuando intereses generales puedan exigirlo. Por su parte, Balaguer Callejón (2001: 163) sugiere que este tipo de sentencias obedece a la necesidad de dar un margen de tiempo al legislador para que pueda dictar una ley que haga posible el acomodo constitucional y se justifican en la medida en que permiten una importante colaboración entre el TC y el legislador. Pertenecen a esta categoría las SSTC 96/1996, de 30 de mayo (RTC 1996/96); 195/1998, de 1 de octubre (RTC 1998/195) —comentada por Agudo González (2000: 87-114)—; 208/1999, de 11 de noviembre (RTC 1999/208); 235/1999, de 20 de diciembre (RTC 1999/235); 194/2004, de 4 de noviembre (RTC 2004/194); 164/2013, de 26 de septiembre (RTC 2013/164); 164/2014, de 7 de octubre (RTC 2014/164); o 13/2015, de 5 de febrero (RTC 2015/13). 
caso, especialmente al Estado, a ponerle fin en el plazo más breve posible» $(\text { STC 208/1999 })^{51}$. Sin embargo, en la mayoría de estas sentencias no se fija un plazo concreto al legislador exhortado a actuar para poner remedio a un estado de cosas que se configura como provisional, ni hay referencia a las consecuencias de su eventual pasividad.

Como excepción, las SSTC 164/2013, 164/2014 y 13/2015, que declararon inconstitucionales los preceptos impugnados por omisión del preceptivo informe previo de la comunidad autónoma previsto en la DA 3. ${ }^{\mathrm{a}} \mathrm{CE}$ y concretado en los respectivos estatutos de autonomía, establecen un plazo de duración de la vacatio de la nulidad de un año, que el TC considera razonable, aunque no precisan las consecuencias del eventual incumplimiento del mismo.

Que el peligro de que el legislador conminado a actuar no lo haga y transcurra más tiempo del razonable es un riesgo real, queda de manifiesto en el caso de la STC 235/1999. Se daba la circunstancia de que la disposición declarada inconstitucional se remitía a otro precepto que, en su día, ya fue considerado inconstitucional (por STC 96/1996). Por aquel entonces se difirió la declaración de nulidad hasta el momento en que se produjera la oportuna actuación del legislador estatal por la que se definieran las bases sobre las que después podrían actuar las comunidades autónomas sus competencias ejecutivas. Tal actuación legislativa debería tener lugar, se precisó, dentro de un plazo de tiempo razonable. Lo cierto es que el TC constata en la sentencia comentada que «[e]l transcurso de más de tres años desde aquel pronunciamiento desborda, como es notorio, el criterio de un «tiempo razonable» para acomodar la norma a la Constitución, lo que ha deparado la anómala pervivencia de una situación contraria al reparto constitucional y estatutario de competencias». A continuación, reitera el imperativo constitucional que sobre el legislador pesa en orden a la reparación con presteza de semejante situación contraria al bloque de la constitucionalidad e insiste en limitarse a declarar inconstitucional el precepto y a recalcar la necesidad de intervención legislativa. Apela, una vez más, al principio de lealtad constitucional para motivar al legislador de modo que propicie una pronta sanación de la situación inconstitucional.

51 En la STC 97/2002, de 25 de abril (RTC 2002/97), la solución fue distinta al concurrir una circunstancia diferencial significativa: la comunidad autónoma implicada había adoptado ya cuando se dicta la sentencia e incluso antes de que se promovieran los recursos de inconstitucionalidad, medidas de protección ambiental de la zona afectada. Por ello no se vio razón para modular los efectos temporales de la nulidad de la ley estatal declarada inconstitucional. 
Pero insiste en que no estima llegado el momento de declarar la nulidad cuya eficacia queda diferida, de nuevo, a un plazo que, aunque califica de determinado, no concreta.

c. Casos en los que se acota territorialmente la nulidad. Son propios de sistemas, como el español, en que existe una distribución competencial entre los poderes legislativos central y territoriales. Esto hace posible la declaración de inconstitucionalidad de una ley estatal por invasión competencial solo respecto de una o varias comunidades autónomas, sin afectar al resto. La ley, en sí, no resulta nula en puridad de conceptos, sino inaplicable en cierto territorio ${ }^{52}$.

d. Sentencias interpretativas. Dentro de las sentencias interpretativas suscitan cuestiones especialmente delicadas las sentencias interpretativas desestimatorias. Son «aquéllas que rechazan una demanda de inconstitucionalidad o, lo que es lo mismo, declaran la constitucionalidad de un precepto impugnado en la medida en que se interprete en el sentido que el Tribunal Constitucional considera como adecuado a la Constitución o, no se interprete en el sentido (o sentidos) que el Tribunal Constitucional considera inadecuados» (STC 5/1981, de 13 de febrero [RTC 1981/5, FJ 6] $)^{53}$. Entre las razones que avalan este modo de proceder, se aduce la obligación de interpretar la ley de conformidad con la $\mathrm{CE}$, la presunción de constitucionalidad de la ley, el principio de conservación de esta o la conveniencia de evitar lagunas normativas ${ }^{54}$. Sin embargo, se trata de una técnica arriesgada que viste al TC con los ropajes de legislador "positivo" y que, en ocasiones, se ha llevado hasta el punto de hacer decir a la ley algo distinto a lo que en realidad dice, produciéndose un salto

52 SSTC 179/1985, de 19 de diciembre (RTC 1985/179), o 227/1988, de 29 de noviembre (RTC 1988/227).

53 Sirvan como ejemplo de una práctica muy extendida, las SSTC 5/1981, de 13 de febrero (RTC 1981/5); 11/1981, de 8 de abril (RTC 1981/11); 14/1981, de 29 de abril (RTC 1981/14); 122/1983, de 16 de diciembre (RTC 1983/122); 108/1986, de 29 de julio (RTC 1986/108); 105/1988, de 8 de junio (RTC 1988/105); STC 56/1990, de 29 de marzo (RTC 1990/56); 62/1990, de 30 de marzo (RTC 1990/62); 76/1990, de 26 de abril (RTC 1990/76); 96/1990, de 24 de mayo (RTC 1990/96); 141/1990, de 20 de septiembre (RTC 1990/141); 341/1993, de 18 de noviembre (RTC 1993/341); 73/2010, de 18 de octubre (RTC 2019/73); 228/2012, de 29 de noviembre (RTC 2012/228); 246/2012, de 20 de diciembre (RTC 2012/246); 3/2015, de 19 de enero (RTC 2015/3); o 5/2015, de 22 de enero (RTC 2015/5).

54 Vidales Rodríguez (2001: 186), Jiménez Campo (1997: 47 y ss.), Montoro Puerto (1991: 110), Aragón Reyes (1987: 38) y Pibernat Doménech (1987b: 80) entre otros. 
cualitativo difícil de justificar cuando el TC no se limita a interpretar, sino que corrige o modifica la norma impugnada para hacerla conforme con la $\mathrm{CE}$ («sentencias manipulativas») $)^{55}$.

e. Casos en que se declara la nulidad matizando su alcance temporal. Desde la STC 45/1989, el TC ha dictado muchas otras en las que a la declaración de inconstitucionalidad aúna la de nulidad de la disposición afectada, pero suaviza el alcance temporal de esta. En ellas consolida la doctrina iniciada de modo decidido con la citada sentencia, que ha sido expuesta en el epígrafe III.3 al cual me remito ${ }^{56}$.

55 Como muestra de la opinión crítica, que comparten muchos autores, puede atenderse a Aragón Reyes (1987: 39) o Ezquiaga Ganuzas (1991: 132). En general, sobre los problemas de las sentencias interpretativas, cuyo análisis excede el objeto de este trabajo, véanse Rubio Llorente (1988: 30 y ss.), Díaz Revorio (2001), Gómez Montoro (2001: 596-598) o Fernández Rodríguez (2007: 128 y ss.).

56 Estas sentencias — que muchas veces tratan sobre cuestiones fiscales, administrativas o relativas a prestaciones de la Seguridad Social - aplican los argumentos de la de STC 45/1989 a diferentes casos. A título de ejemplo, cabe citar las SSTC 55/1990, de 28 de marzo (RTC 1990/55); 128/1994, de 5 de mayo (RTC 1994/128); 41/2013, de 14 de marzo (RTC 2013/41); 137/2003 (RTC 2003/137); 184/2011, de 23 de noviembre (RTC 2011/184); 27/2012, de 1 de marzo (RTC 2012/27); 150/2012, de 5 de julio (RTC 2012/150); 40/2014, de 11 de marzo de 2014 (RTC 2014/40); 178/2014, de 21 de octubre (RTC 2014/178); 81/2016, de 25 de abril (RTC 2016/85); o 140/2016, de 21 de julio (RTC 2016/149). En ellas, el TC ejerce su potestad de concretar el alcance de la nulidad asociada a la declaración de inconstitucionalidad. Así, estima que no son susceptibles de revisión las situaciones jurídico-tributarias producidas al amparo de la disposición declarada inconstitucional (SSTC 137/2003 y 184/2011). Mantiene el resultado de procesos selectivos en el ámbito de la contratación pública que habían finalizado mediante resolución administrativa firme al tiempo de publicarse la sentencia, aunque se declare inconstitucional la norma que regulaba la valoración de méritos (STC 27/2012). Respeta las ayudas ya concedidas con base en la disposición afectada (STC 150/2012). Establece que los convivientes de hecho que podrían haberse beneficiado de la declaración de inconstitucionalidad del art. 174.3, párrafo quinto LGSS a los efectos de solicitar una pensión de viudedad, solo podrán hacerlo en el caso de que no hubiera recaído todavía resolución judicial o administrativa firme (la inconstitucionalidad/nulidad derivada del trato discriminatorio que establecía el precepto en función de la residencia o no del solicitante en una CA con Derecho civil propio que hubiera aprobado legislación específica sobre parejas de hecho) (STC 40/2014). Mantiene las situaciones administrativas firmes en materia urbanística (licencias, acuerdos aprobatorios de procedimientos de equidistribución) sin que se 
Llegados a este punto, es el momento de contrastar los argumentos desgranados en las páginas anteriores con los que manejan las sentencias dictadas

pueda formular reclamación alguna destinada a obtener la cuantía correspondiente al aprovechamiento urbanístico dejado de percibir o efectivamente cedido por la aplicación de los preceptos inconstitucionales (STC 178/2014). Declara que los convivientes de hecho que no cumplían el requisito de tener hijos comunes para poder acceder a la pensión de viudedad (estimado inconstitucional) no pueden reclamar ahora la pensión si no la solicitaron en su momento dentro del plazo legal habilitado al efecto ( $y$ ya transcurrido) dado que este plazo no ha sido cuestionado en el recurso y no cabe extender al mismo la declaración de inconstitucionalidad por conexión o consecuencia (SSTC 41/2013 y 81/2016). Quizá debería haberse valorado que muchos no la reclamaron por no cumplir el requisito de tener hijos comunes (no sabemos, porque el TC no lo indica, si, en estas dos sentencias, que aplican de modo rígido el respeto de situaciones administrativas firmes, tuvo algún peso la incidencia económica que la solicitud de estas pensiones hubiera tenido para las arcas públicas); sobre estas sentencias, pueden verse los comentarios de Díaz Aznarte (2016: 167 y ss.), Martínez Barroso (2016: 292 y ss.) o Cavas Martínez (2014: 183 y ss.). O, en la STC 140/2016, declara que no procede ordenar la devolución de las cantidades pagadas por los justiciables en relación con las tasas judiciales declaradas nulas, tanto en los procedimientos administrativos y judiciales finalizados por resolución firme, como en aquellos no finalizados en los que el obligado al pago de la tasa la satisfizo sin impugnarla. En relación con el último supuesto, el TC considera relevante no solo el perjuicio que tal devolución reportaría a la Hacienda Pública, sino el hecho de que la tasa se declara inconstitucional porque lo elevado de su cuantía impide el acceso a la Justicia en sus distintos niveles (véase art. 24.1 $\mathrm{CE}$ ). Tal situación no puede predicarse de quienes la han pagado y por lo tanto han logrado impetrar la potestad jurisdiccional que solicitaban, sin sufrir una lesión del derecho fundamental mencionado, que deba repararse mediante la devolución del importe satisfecho.

Algunos de los pronunciamientos versan sobre normas procesales. En estos casos, el TC señala que, en orden a los procesos en curso, no surtirá efecto la declaración de nulidad respecto de las actuaciones procesales practicadas de acuerdo a la norma declarada inconstitucional. Tal declaración, en consecuencia, solo producirá efectos a partir de la fecha de su notificación en el proceso de origen, y de la fecha de su publicación en el BOE en los demás casos (STC 1990/55, relativa a la competencia judicial respecto de delitos cometidos por las fuerzas y cuerpos de seguridad del Estado); o que los efectos de la sentencia de inconstitucionalidad solo se extenderán, en los procesos pendientes, a los actos procesales que hayan de dictarse a partir de la fecha de publicación de la sentencia, correspondiendo a los órganos judiciales competentes llevar a cabo las adaptaciones procesales que estimen necesarias (STC 128/1994, sobre procedimiento de ejecución del Banco Hipotecario). 
en relación con leyes civiles que se declara inconstitucionales en todo o en parte, y en las que el TC, bien excluye la nulidad, bien matiza el alcance en el tiempo de la misma ${ }^{57}$. Extraer conclusiones que puedan orientar la solución de los problemas prácticos que se susciten en relación con el alcance temporal de la declaración de inconstitucionalidad de este tipo de normas.

\section{ANÁLISIS DE LA CUESTIÓN EN RELACIÓN CON LAS LEYES CIVILES EN PARTICULAR. ESPECIAL REFERENCIA A LAS LEYES VALENCIANAS DECLARADAS INCONSTITUCIONALES}

\section{PLANTEAMIENTO}

Como he anticipado en la introducción, la cuestión cobró actualidad el pasado año a raíz de tres sentencias de Pleno en las que se declararon inconstitucionales las leyes civiles valencianas que ordenaban algunas parcelas básicas del derecho de familia: SSTC 82/2016, de 28 de abril (RTC 2016/82); 110/2016, de 9 de junio de 2016 (RTC 2016/110); y 192/2016, de 16 de noviembre (RTC 2016/192), relativas, respectivamente, a la Ley 10/2007, de 20 de marzo, de Régimen Económico Matrimonial Valenciano; la Ley 5/2012, de 15 octubre, de Uniones de Hecho Formalizadas de la Comunidad Valenciana; y la Ley 5/2011, de 1 de abril, de Relaciones Familiares de los Hijos e Hijas cuyos Progenitores no Conviven. La fundamentación jurídica y el fallo, reiterados — mutatis mutandi- en estas resoluciones, se sitúan claramente en una línea continuista de la doctrina tradicional del TC sobre la distribución competencial en materia de legislación civil (su interpretación del art. 149.1.8. $\left.{ }^{\mathrm{a}} \mathrm{CE}\right)^{58}$, de la que se aparta, en sus votos particulares, el magistrado

57 Quedan fuera del análisis las sentencias que se limitan a declarar la inconstitucionalidad y nulidad de leyes civiles sin pronunciarse sobre el alcance temporal de tal declaración.

58 El TC niega competencia sobre legislación civil a la Comunitat Valenciana salvo que exista alguna ley o costumbre histórica sobre la materia al entrar en vigor la CE (véase STC 121/1992, de 28 de septiembre [RTC 1992/121]), lo que no se ha probado que suceda respecto de ninguna de las tres leyes afectadas. No era esta la única solución posible. El TC no se halla autovinculado por sus propias decisiones de modo absoluto, aunque la seguridad jurídica y el respeto al principio de igualdad exigen que no se aparte sin fundamento de su doctrina pasada. He defendido en otras ocasiones —Mas Badia (2009: 645-647 y 2016: 2) — que tal fundamento podría encontrarse en la evolución de la realidad social (cfr. art. 3.1 CC). Podría haberse planteado el Alto Tribunal si la evolución de la cuestión, manifestada por la acción legislativa de las comunidad autónoma incluida una reforma 
Xiol Ríos. Pese a su posición conservadora, el TC ha esperado ocho años para dictar la primera de las tres sentencias citadas (STC 82/2016). Posiblemente, haya influido el cariz delicado de la cuestión alrededor de la cual gravitan implicaciones jurídicas, sociales y políticas. Parafraseando a Otto Bachof (1985: 33-34), diríase que, en este tipo de casos, aunque se decide sobre cuestiones jurídicas y no de oportunidad política, las consecuencias políticas de tales decisiones son importantes. Esto puede alimentar la discusión «sobre cuáles deban ser los límites de este poder «antimayoritario» (el de la jurisdicción constitucional) en relación con los otros poderes "políticos» del Estado» (Rubio Llorente, 1988: 12). Sea como sea, no voy a ocuparme de las razones de la declaración de inconstitucionalidad, sino de sus efectos. En relación con ellos, estas sentencias presentan algunas notas que las singularizan respecto de otras en las que el TC ha plasmado su doctrina acerca de la delimitación de la eficacia temporal de la declaración de inconstitucionalidad/nulidad. Se dedicará una especial atención a su análisis y se efectuará el debido contraste con las conclusiones alcanzadas en los epígrafes anteriores, en los que he analizado el marco normativo y la doctrina del TC en relación con esta cuestión en general. Junto con ellas se analizarán otras sentencias emblemáticas en las que el TC declaró la inconstitucionalidad de preceptos de carácter civil o relacionados con materia civil y matizó de modo expreso el alcance temporal de su fallo, a algunas

del Estatuto de Autonomía orientada por una finalidad clara justifica, asimismo, una evolución de su interpretación del art. 149.1.8. ${ }^{a} C E$ en un sentido más autonomista. Esto no significa alterar la jerarquía entre un Estatuto de Autonomía (Ley Orgánica) y la CE; contrastados ambos, aquel debe subordinarse a esta. Pero las normas que se comparan han sido decantadas a partir de una labor de interpretación. Lo que sugiero es la posibilidad de una interpretación evolutiva de las disposiciones constitucionales, guiada por un cambio en las convicciones sociales reflejado, entre otros factores, en la actividad decidida del Parlamento autonómico volcada en un Estatuto de Autonomía y las leyes que lo desarrollan, siempre que esa interpretación quepa en el texto que sirve de vehículo a la norma (el «allí donde existan» del art. 149.1.8. $\left.{ }^{a} \mathrm{CE}\right)$. Y que cabe lo demuestran, entro otros argumentos, los votos particulares del magistrado Xiol Ríos en las tres sentencias de referencia. A favor de la posibilidad de cambios de criterio en la jurisprudencia constitucional, se manifiestan, entre muchos otros, Arozamena Sierra (1979: 260), Bocanegra Sierra (1982), Rubio y Aragón (1984: 831-886), Aparicio Pérez (1983: 944), Jiménez Campo (1997: 29), Balaguer Callejón (2001: 147) o Vidales Rodríguez (2001: 218), que subraya cómo, de hecho, estos cambios, se han producido en diversas ocasiones aunque no es habitual que el TC lo manifieste de modo expreso. O, en relación precisamente con el art. 149.1.8 . ${ }^{\circ} \mathrm{CE}$, García Rubio (2017: 26 y ss.), en un recientísimo trabajo en el que, una vez más, aborda de forma lúcida el «aparente irresoluble problema del futuro de Derecho civil español desde el punto de vista de su estructuración territorial». 
de las cuales ya me he referido en la primera parte de este trabajo al hilo de consideraciones más generales ${ }^{59}$.

\section{CASOS DE DECLARACIÓN DE INCONSTITUCIONALIDAD SIN NULIDAD DE LEYES CIVILES}

Varias de las sentencias en que el TC rompe el binomio inconstitucionalidad/nulidad versan sobre materia civil. Es el caso de las SSTC 138/2005 y 273/2005 (dies a quo en las acciones de filiación), 131/2010 y 132/2010 (internamiento forzoso de personas que padezcan trastornos psíquicos) y 222/1992 (subrogación mortis causa de las parejas de hecho en los arrendamientos urbanos). Han sido analizadas supra, en el epígrafe III.4., al cual me remito. No tiene sentido repetir las consideraciones que allí se efectuaron.

Solo deseo insistir en que el TC basa su fallo en algunos de sus argumentos tradicionales. En el caso del internamiento forzoso (SSTC 131/2010 y 132/2010), resultó especialmente relevante que la causa de la inconstitucionalidad no fuera una razón de fondo (no se discutía la pertinencia en sí de la medida de internamiento), sino la circunstancia de no haberse respetado el rango normativo de ley orgánica al regular una materia sujeta a esta. Además, la declaración de nulidad hubiera generado un vacío legislativo indeseable con consecuencias más perniciosas todavía. Por su parte, en las SSTC 138/2005 y 273/2005 relativas al dies a quo de determinadas acciones de filiación, la inconstitucionalidad derivaba de haberse omitido en la fijación de mismo una circunstancia que debería haber sido tenida en cuenta (el conocimiento de la verdad biológica por el legitimado activamente). La sentencia se limita a aplicar un argumento que ya se utilizó en la STC 45/1989 y en otras posteriores: no es necesaria la vinculación entre inconstitucionalidad y nulidad cuando la razón de la inconstitucionalidad reside, no en determinación textual alguna del precepto impugnado, sino en su omisión. Si se declarase la nulidad no solo no se repararía la inconstitucionalidad, sino que se dañaría sin razón a los legitimados por la norma para interponer la acción. También nos encontramos ante una omisión, con llamada a los mismos argumentos, en el supuesto de la STC 22/1992, aunque aquí se halla vinculada a una lesión del principio de igualdad. En efecto, del precepto impugnado (el antiguo art. $58 \mathrm{LAU}$ ) un trato discriminatorio entre las personas casadas y los convivientes de hecho. El carácter civil de la materia no supone en estos casos especialidad alguna.

59 En coherencia con el planteamiento de este trabajo, no se analizan aquellas sentencias en las que el TC declara inconstitucional y nula alguna ley civil, pero sin pronunciarse sobre el alcance temporal de tal declaración. 


\section{CASOS DE LIMITACIÓN DEL ALCANCE RETROACTIVO DE LA NULIDAD DE LEYES CIVILES DECLARADAS INCONSTITUCIONALES}

\subsection{La STC 82/2016, relativa a la Ley 10/2007, de 20 de marzo, de Régimen Económico Matrimonial Valenciano ${ }^{60}$}

\section{a) Presupuestos preliminares}

La Ley 10/2007, de 20 de marzo, de Régimen Económico Matrimonial Valenciano (LREMV) [modificada por la Ley 8/2009, de 4 de noviembre], se promulgó con la intención de ofrecer una regulación completa y sistemática de los aspectos que según la dogmática tradicional integran el régimen económico del matrimonio. Su aspecto más novedoso, a efectos prácticos, fue la introducción de la separación de bienes como régimen legal supletorio en lugar de la sociedad de gananciales. El cambio se implantó con normalidad en la sociedad valenciana.

La STC 82/2016 declara inconstitucional y nula la totalidad de la LREMV ${ }^{61}$ y dedica el FJ 8 a precisar el alcance de esta declaración. En primer lugar, acota su eficacia temporal. Dice que «no afectará a las situaciones jurídicas consolidadas». Como tal declaración genérica, nada nuevo hay si la confrontamos con la doctrina que elabora el TC sobre esta materia. Sin embargo, tal afirmación deja muchos cabos sueltos, pues no aclara lo que deben considerarse situaciones consolidadas en este caso.

A continuación, el TC explica las razones en que basa esta conclusión. Entiende «que, si durante la vigencia de la LREMV que ahora se declara inconstitucional, los cónyuges sujetos al derecho civil foral valenciano no han hecho uso de su facultad de capitulación se debe a su voluntad de someterse al régimen subsidiario en primer grado que aquella establece». Esto es, los matrimonios casados bajo la vigencia de la ley que no capitularon para establecer otra cosa mantienen la separación de bienes, no pasan automáticamente al régimen de gananciales (sobre esto no hay duda alguna); pero no en virtud de la fuerza vinculante de una ley declarada nula por inconstitucional, sino por

60 En este epígrafe retomo y profundizo en ideas que avancé en Mas Badia (2016: 1-13) trabajo que recoge la versión escrita de la ponencia impartida, por invitación de la Cátedra de Derecho Foral Valenciano, en el Simposium sobre el Derecho Civil Valenciano celebrado en Valencia del 3 al 7 de octubre de 2016.

61 Aunque, por razones suficientemente expuestas en la sentencia, se considera el recurso extemporáneo respecto de un bloque de artículos, estos también acaban declarándose inconstitucionales por conexión o consecuencia (art. 39 LOTC), al entender que la vulneración competencial concurre en todas las disposiciones de la ley. 
la fuerza vinculante de su autonomía privada, que implícitamente se deduce de no haber otorgado capitulaciones pudiendo hacerlo. Seguidamente, el TC abunda en la idea con un excurso sobre la prevalencia de la autonomía privada en una materia, el derecho civil, en la que - dice-, solo subsidiariamente entra en juego la norma legal.

A modo de recapitulación, finaliza reafirmándose en su conclusión y en las razones que la fundamentan, pero con un matiz en la forma de expresarlo que merece alguna reflexión. El FJ 8 se cierra con la siguiente afirmación:

Por tal motivo, rigiendo en esta materia el principio capitular y siendo respetuoso con las libertades individuales, tras la publicación de esta Sentencia, seguirán rigiéndose por el mismo régimen económico matrimonial que hubiera gobernado sus relaciones, salvo que su voluntad contraria sea manifestada mediante las oportunas capitulaciones. Por lo demás, la declaración de nulidad de la LREMV no ha de afectar a las relaciones de los cónyuges con los terceros que, en todo caso, se regirán por el régimen matrimonial vigente en cada momento».

En este último párrafo, la fórmula utilizada no hace referencia expresa al régimen legal supletorio, sino que es más amplia: alude al régimen económico matrimonial que hubiera gobernado las relaciones de los cónyuges y de estos con terceros. Las interpretaciones posibles son, en teoría, dos: entender que el TC se refiere al régimen concreto que puede ser elegido por los cónyuges y en cuyo defecto se aplica el legal (separación de bienes u otro) o considerar que apunta al conjunto de todas las normas que rigen los aspectos económicos del matrimonio, integrado por ese régimen concreto, acerca del que hay amplísima libertad de pacto, más el bloque de normas comunes aplicables a todos los matrimonios por igual, con independencia de que se rijan por la separación de bienes, germanía, gananciales, etc. (el denominado régimen económico matrimonial primario). Normas comunes que, en principio, no son disponibles por las partes, sino que quedan al margen de su autonomía privada. En mi opinión, existen datos de los que puede deducirse que el TC piensa en el primero de los sentidos sugeridos ${ }^{62}$. Sin embargo, aunque se interprete que las determinaciones de la sentencia sobre el alcance temporal de la nulidad se refieren a la separación de bienes como régimen legal y no a las normas básicas

62 Sigue hablando del principio capitular y del respeto de la libertad de los cónyuges, lo que es determinante en la elección del régimen de separación de bienes, gananciales u otro, pero no en la de las normas comunes básicas que se aplican imperativamente. Y afirma que seguirán rigiéndose por el mismo régimen salvo voluntad diferente manifestada en capitulaciones matrimoniales lo que, de nuevo, solo puede aludir a lo primero. 
comunes a todos los matrimonios, esto no significa que no puedan suscitarse dudas y problemas en relación con el alcance de la sentencia sobre estas últimas. Lo que significa - quiero insistir en ello- es que el TC no ha ofrecido información al respecto.

A la vista de lo anterior, dividiré el análisis que sigue en tres puntos, que merecen especial atención, relativos al alcance de la declaración de inconstitucionalidad/nulidad de la LREMV en relación con la persistencia de la sujeción al régimen de separación de bienes, las normas del llamado régimen económico matrimonial primario y las germanías pactadas vigente la ley, consciente de que hay otros que pueden plantear problemas (por ejemplo, vinculados a las donaciones por razón de matrimonio o derivados del diferente régimen de capacidad para otorgar capitulaciones matrimoniales).

b) La persistencia de la sujeción al régimen de separación de bienes

En los concisos artículos de opinión alumbrados tras la STC 82/2016 se insiste en que, a partir de ahora, habrá que distinguir tres situaciones cronológicamente delimitadas, siempre con referencia a matrimonios sujetos, en virtud de los arts. 9, 14 y 16 CC, al derecho civil valenciano: 1) matrimonios anteriores a la entrada en vigor de la LREMV (01.07.2008); 2) matrimonios celebrados desde la entrada en vigor de la LREMV hasta el día siguiente a la publicación de la STC 82/2016, de 28 de abril en el $B O E$, el 31 de mayo de $2016^{63}$; y 3) matrimonios contraídos con posterioridad al 1 de junio de 2016.

Los primeros y los terceros no estaban ni estarán sujetos a la LREMV. Son los segundos los que plantean problemas. En relación con ellos suele despacharse la cuestión afirmando que conforme con la STC 82/2016 seguirán sometidos al régimen de separación de bienes si no pactaron otro distinto, o al que hubieran convenido en capitulaciones matrimoniales ${ }^{64}$, sin perjuicio de poder alterarlo en el futuro a través de las oportunas capitulaciones. En alguna ocasión se va un poco más allá y se plantea la duda de si este régimen de separación de bienes al que, en su caso, seguirán sujetos los cónyuges mientras no convengan otro distinto, es el regulado por la ley valenciana o el del CC, aconsejando algunos notarios a los particulares que

63 Esta fecha es la que marca el momento en que tiene efecto la declaración de nulidad de las disposiciones inconstitucionales de acuerdo con los arts. 38.1 y 39.1 LOTC.

64 Si excluyeron la separación de bienes sin pactar otro régimen, como la LREMV no fijaba régimen legal supletorio de segundo grado, regía el de gananciales por aplicación del CC como derecho supletorio. 
se capitule para aclararlo. No cabe duda de que el régimen que persiste es la separación de bienes diseñada por la LREMV, desde el momento en que se trata de mantener una situación consolidada originada bajo la vigencia de la ley declarada inconstitucional y nula, matizándose el alcance de la retroactividad. En cuanto a unas eventuales capitulaciones aclaratorias, no serían tales, pues el régimen se aplicó como legal supletorio y no en virtud de capitulaciones anteriores cuya interpretación se pretenda clarificar ahora. Si los consortes capitulan tras la STC 82/2016 para declarar que quieren la separación de bienes del CC serán unas capitulaciones modificativas, que deben entenderse sin perjuicio de tercero (art. 1317 CC).

Todavía hay otra circunstancia que se debe considerar. Vigente la LRE$\mathrm{MV}$, algunos abogados y notarios aconsejaban a sus clientes que otorgaran capitulaciones para pactar separación de bienes en previsión de una eventual declaración de inconstitucionalidad de la Ley y de la incertidumbre acerca de sus consecuencias. Algunos jueces encargados del Registro Civil se negaban a indicar estas capitulaciones por entender que no cabía otorgarlas para pactar el mismo régimen que establecía la ley como legal supletorio. En cualquier caso, si en esas capitulaciones se estipuló la separación de bienes del CC, a ella habrá que estar, aunque las diferencias entre esta y la que regula la LREMV sean mínimas ${ }^{65}$.

He dejado para el final una última reflexión crítica sobre la fundamentación que ofrece el TC para afirmar la continuidad del régimen de separación de bienes de los matrimonios valencianos concertados vigente la LREMV que no pactaron otro distinto. La STC 82/2016 sustenta esta conclusión en el principio de libertad o de autonomía privada, lo que resulta cuestionable. El régimen legal supletorio, sea el que sea, no se aplica por ser el que tácita o presuntamente han elegido los cónyuges, sino por la necesidad de que exista un régimen económico en su matrimonio unida a determinada jerarquía de fuentes reguladoras: primero la autonomía privada y, en su defecto, la ley. La norma que establece el régimen legal supletorio, basada en una opción de política legislativa, es una norma dispositiva que opera en defecto de pacto y con

65 Manifiesta una diferencia de régimen el art. 46, segundo inciso LREMV, sobre atribución de bienes muebles de uso personal o destinados directamente a la actividad de uno de los cónyuges, cuando no se pueda acreditar a cuál de los dos pertenecen. Por otra parte, el derecho a una compensación por el trabajo para la casa no se contiene en sede de separación de bienes, sino entre las normas comunes a todos los matrimonios (art.13, en relación con el 12, ambos de la LREMV) y su tenor es algo diferente al del art. 1438 CC. 
independencia de cuál sea la preferencia no manifestada de los cónyuges ${ }^{66}$. El argumento de la seguridad jurídica, que conduce al respeto de las situaciones consolidadas, hubiera bastado para llegar a la misma conclusión y es el que debería haberse utilizado.

\section{c) Los efectos sobre el llamado régimen económico matrimonial primario}

Los problemas no se agotan con los relativos a la persistencia del régimen de separación de bienes, pese a que la STC 82/2016 se ciña a ellos. Entre las cuestiones que merecen un análisis detenido por sus importantes repercusiones prácticas destaca la necesidad de precisar qué sucede con las normas contenidas en los capítulos I, II y III LREMV — relativos a las disposiciones generales, el levantamiento de las cargas del matrimonio y la disposición de la vivienda habitual de la familia, respectivamente- . Su aplicación no depende de que los cónyuges se rijan por la separación de bienes o por otro régimen diferente pactado en capitulaciones. Son normas aplicables a todos los matrimonios, imperativas salvo matices y, por tanto, excluidas de la libre disponibilidad de las partes. Además, presentan algunas diferencias significativas con el régimen del CC.

Pensemos, por ejemplo, en un matrimonio concertado entre el 1 de julio de 2008 y el 1 de junio de 2016. ¿Qué ocurre si el día de mañana uno de los cónyuges, propietario de la vivienda habitual, la enajena a un tercero sin el asentimiento de su consorte? ¿Podrá este, como señalaba el art. 18 LREMV, «exigir judicialmente que las cantidades obtenidas por el cónyuge que dispuso del inmueble sin su consentimiento se destinen a la adquisición de una vivienda habitual suficiente para la familia y de características análogas a la dispuesta, pudiendo igualmente solicitar en sede judicial la adopción de las medidas cautelares pertinentes para la efectividad de la reinversión sobre los bienes privativos del cónyuge disponente»? —el CC no reconoce este derecho-. O si en un futuro pide uno de los cónyuges una compensación económica por el trabajo realizado para la casa, ¿deberán aplicarse las reglas de los arts. 12 a 15 LREMV? ¿Qué hay

66 En este sentido, Bercovitz Rodríguez-Cano (2016: 1-4) califica el argumento de falso, pues «desconoce cuál es el valor del derecho supletorio, cuya aplicación no viene respaldada necesariamente por la voluntad de los particulares, es decir, de las partes, frecuentemente ignorantes del contenido del mismo, sino por la solución que el legislador considera preferible, basada en la ponderación de intereses que el mismo realiza, sin perjuicio de que deje abierta la posibilidad de un margen de ejercicio de la autonomía privada en base a la voluntad de las partes». 
del derecho de predetracción del ajuar doméstico? ¿Se regirá por el CC o por la Ley 10/2007?

Si se afirma que los matrimonios valencianos celebrados vigente la LREMV siguen sujetos al bloque de normas comunes conocidas como régimen económico matrimonial primario de esta ley y no a sus equivalentes en el CC, habrá que apoyarlo en argumentos distintos al de la autonomía privada porque estamos hablando de normas imperativas, excluidas del poder de disposición de las partes, salvo en algunos extremos. Por tanto, vano es decir que del hecho de no haber realizado los cónyuges capitulaciones matrimoniales mientras estaba vigente la LREMV se deduce su voluntad de regirse por estas normas y de ahí extraer conclusiones, pues esta voluntad en relación con la aplicación de estas era, salvo algún matiz, irrelevante por tratarse de disposiciones cuya aplicación, en general, no podrían haber excluido los cónyuges aunque hubieran querido. Las claves que nos pueden dar la solución son otras y podemos hallarlas en la doctrina establecida por el TC en relación con el alcance temporal de la declaración de inconstitucionalidad de las leyes, que he analizado en páginas anteriores. De esta doctrina resulta que la no afección de la declaración de inconstitucionalidad de una ley a situaciones consolidadas bajo la vigencia de aquella puede basarse directamente en el principio de seguridad jurídica (véase art. 9.3 CE, en relación con el art. 40.1 LOTC interpretado de forma flexible por el TC). A este argumento podría añadirse el de la consideración del régimen económico del matrimonio en la LREMV como un sistema unitario y coherente.

A partir de aquí, habrá que determinar casuísticamente las situaciones que se consideran consolidadas a efectos de su mantenimiento. A tal fin, cabe recordar que el TC ha realizado una interpretación flexible del art. 40.1 LOTC, entendiendo de modo reiterado que no solo deben respetarse las situaciones amparadas por sentencia firme (cosa juzgada en sentido estricto), sino también las situaciones administrativas firmes. Hay que tener en cuenta que las sentencias en que se introdujo y fue asentando esta doctrina — analizadas en el epígrafe III-, se referían mayoritariamente a situaciones consolidadas de índole administrativa o fiscal. Sin embargo, con base en el mismo principio de seguridad jurídica (art. 9.3 CE) en que se sustenta la anterior conclusión, cabe defender en el ámbito del derecho privado el respeto de «situaciones consolidadas», aunque no quepa calificarlas de «situaciones administrativas firmes». Esta interpretación flexible podría razonarse también a partir del art. 2.3 CC, en cuanto establece la regla general de irretroactividad de las leyes, y en las disposiciones transitorias del propio CC, que dejan a salvo los derechos adquiridos bajo la 
legislación anterior ${ }^{67}$. Es cierto que en el caso que se analiza no se trata de fijar el alcance de la sucesión de dos normas en el tiempo cuando una ley posterior deroga a la anterior, sino de resolver los problemas de retroactividad o irretroactividad que se originan cuando una ley que estuvo vigente y se aplicó durante un tiempo es declarada nula por inconstitucional. Pero, a los efectos que ahora interesan, los fenómenos son paralelos en cuanto que en ambos hay que determinar cómo afecta el cambio a los hechos, actos y situaciones jurídicas nacidas bajo la vigencia de la ley, bien derogada, bien declarada inconstitucional ${ }^{68}$. En última instancia la cuestión desemboca en un problema de sucesión de normas en el tiempo para cuya solución puede resultar útil la distinción entre retroactividad de grado máximo, medio y mínimo ${ }^{69}$. En la medida en que el TC no se pronuncie con la suficiente precisión sobre el alcance respecto del pasado y pro futuro del fallo de inconstitucionalidad, será el intérprete el que tendrá que resolver en cada caso atendiendo a las circunstancias que concurran ${ }^{70}$.

67 Egusquiza Balmaseda (2013: 33) en relación con la STC 93/2013, señala que, ante la carencia en aquella de un régimen transitorio reconocido, habrá que acudir a las reglas que comúnmente se han venido aceptando como aplicables a estos casos: las previstas como régimen de derecho transitorio en el CC. Como señala Díaz Aznarte (2002: 116), en las reglas de derecho transitorio incluidas en el CC se contienen una serie de criterios generales que podrían servir de orientación general de cara a la resolución de conflictos de normas en el tiempo. Sobre el complejo concepto de «derecho adquirido» en la Regla Transitoria Preliminar del CC, véase Colina Garea (2013b: 13388 y ss.).

68 Así lo ha entendido Egusquiza Balmaseda (2013: 31) con referencia a la declaración parcial de inconstitucionalidad de la Ley de Navarra sobre Parejas de Hecho.

69 Sobre esta distinción, reflexionan De Castro y Bravo (1984: 648-649), Suárez Collía (1991: 63 y ss.), Salvador Coderch (1991: 13 y ss.), Coca Payeras (1992: 415 y ss.), Verdera Izquierdo (2006: 85 y ss.), García Rubio (2010: 54) o Colina Garea (2013a: 110-111).

$70 \mathrm{Al}$ concretar la eficacia temporal tanto de la «lex posterior», como de la declaración de inconstitucionalidad y su secuela — la nulidad de la disposición-, debe atenderse como principio rector al de seguridad jurídica (art. 9.3 CE). Pero las cosas funcionan de modo diferente en uno y otro supuesto. En el caso de la derogación de una ley, la seguridad jurídica se logra a través del principio de irretroactividad. La derogación es un fenómeno que responde a una actuación (expresa o tácita) del legislador, que sustituye la regulación vigente en un momento dado por otra nueva. A partir de ahí, la irretroactividad de la ley posterior que deroga a la anterior es solo una regla que admite excepciones (véase art. 2.3 CC); puede ser enervada por el legislador salvo en la hipótesis de normas sancionadoras no favorables o restrictivas de derechos individuales (art. 9.3 CE), precisando, en su caso, el alcance de la retroactividad mediante un régimen transitorio. Cuando el legislador se decanta por la eficacia retroactiva de 
Volvamos a las normas del régimen económico matrimonial primario de la LREMV y a las preguntas que antes planteaba. Creo que puede afirmarse con bastante seguridad que habrán de respetarse aquellas prestaciones ya satisfechas o derechos ya ejercitados cuando se declara inconstitucional la LREMV: por ejemplo, la prestación por compensación del trabajo para la casa o la reinversión del precio obtenido por la disposición inconsentida de la vivienda habitual o el derecho de predetracción ya aplicado. Y todos aquellos derechos/obligaciones reconocidos por sentencia firme o respecto de los que quepa hablar de situación administrativa firme (también la LREMV tenía, por ejemplo, unas implicaciones fiscales). En suma: efectos ya consumados cuando se publica en el $B O E$ la sentencia de inconstitucionalidad. Más dudosa puede resultar la solución en relación con aquellos derechos que nacen al cumplirse unos requisitos que se dieron antes de que se declarase la ley inconstitucional, pero que aun no se han reclamado o sobre los que se halle pendiente un litigio o se estén tramitando administrativamente. Por ejemplo, si los cónyuges se divorcian antes de publicarse la Sentencia 82/2016, ¿ ¿pueden pedir prestación por contribución al trabajo para la casa según la ley valenciana? O, si se vendió la vivienda habitual de la familia antes de publicarse aquella sentencia, ¿̨puede pedirse la reinversión regulada en el art. 18 LREMV? Finalmente, parece también bastante seguro, que si no se dieron los requisitos de los que depende el efectivo nacimiento del derecho antes de publicarse la sentencia de inconstitucionalidad, estaríamos ante meras expectativas y no situaciones consolidadas a respetar. De todos modos, sigue existiendo un factor que genera cierta incomodidad a la hora de afirmar con rotundidad esta última conclusión: si el régimen económico matrimonial concreto y las normas básicas comunes en la LREMV formaban un sistema unitario y coherente, ¿̇tiene sentido afirmar la continuidad de la separación de bienes de la LREMV para los cónyuges que entraron a

la «lex posterior» es porque, tras valorarlo, se imponen sobre la seguridad jurídica, a la que tiende la irretroactividad, otras consideraciones de justicia y progreso (Verdera Izquierdo, 2006: 39 y ss.). En cambio, la inconstitucionalidad de la ley y su declaración no obedecen, como es lógico, a la voluntad del legislador, ni a un afán de cambio, mejora o progreso del ordenamiento jurídico, sino a defectos intrínsecos de la disposición afectada, de su contenido o del procedimiento por el que se creó. En coherencia con ello, en la declaración de nulidad consiguiente a la de inconstitucionalidad se parte, como principio, de la ineficacia de la ley declarada inconstitucional, ineficacia que se debe a razones de jerarquía normativa entre la ley y la CE. Pero como la disposición entró en vigor y los ciudadanos rigieron sus relaciones por ella, el TC en aras de la seguridad jurídica puede matizar el alcance ex tunc de la nulidad de la disposición afectada. 
regirse por ella conjugado pro futuro con un régimen económico matrimonial primario parcialmente diferente, como es el del CC?

\section{d) Las germanías pactadas vigente la LREMV}

La ley valenciana permitía templar la radical separación de bienes por medio de una figura, la germanía, a cuya regulación destinó un título entero, el II (arts. 38-43). La germanía podía constituir un verdadero régimen económico matrimonial de comunidad —universal o limitada, según lo configurasen los cónyuges en carta de nupcias - o modelarse como una situación jurídica que afectase únicamente a determinados bienes, sometidos por voluntad de los cónyuges a un régimen jurídico peculiar, de mancomunidad, dentro del marco general de un régimen de separación u otro distinto. Cuando la ley se promulgó, aventuré que, de tener la germanía viabilidad, no sería como régimen económico matrimonial autónomo, sino por la vía de agermanar bienes concretos dentro de un régimen de separación de bienes, como se confirmó. La germanía, en cualquiera de sus modalidades, tenía necesariamente un origen voluntario. En ningún caso operaba como régimen legal supletorio, ni de primer ni de segundo grado. Por tanto, esta figura se encuentra amparada por la libertad de pactos, que también reconoce el CC (de hecho, podría haberse convenido perfectamente y ser válida por cónyuges sujetos a este). Por ello, la declaración de inconstitucionalidad de la ley no afecta a la persistencia de las germanías estipuladas. Otra cosa es que al haberse declarado nula la LREMV nos encontremos con una ordenación falta de dinamismo, lo que se agrava ante las notables lagunas y deficiencias de la regulación de la germanía en la $\mathrm{LREMV}^{71}$. Sea como sea, si los cónyuges pueden, en el marco de la autonomía privada, adoptar como régimen económico de su matrimonio el de un ordenamiento extranjero o el de cualquier derecho autonómico o, incluso, diseñar a la carta el suyo propio (aunque este sea un supuesto más bien de laboratorio), pueden convenir uno que se rija por las normas de una ley derogada o, como en el caso de la germanía, de una ley declarada inconstitucional no por razones de fondo — esto es esencial—, sino por falta de competencia. En definitiva, estamos ante una autorregulación de las partes (la fuerza normativa de la germanía no nace de la LREMV, sino del convenio), aunque el contenido de esta queda determinado, indirectamente, por remisión a una ley que ya no está en vigor.

71 Basta pensar en la figura de la "germanía continuada» — art. 42.1. in fine- o en el peculiar sistema de liquidación — véase. art. 43.2-. Sobre estas lagunas y deficiencias, tuve ocasión de profundizar en Mas Badía (2010: 273-388). 


\subsection{Las sentencias que declaran la inconstitucionalidad de algunas leyes autonómicas sobre uniones de hecho, con especial consideración de la STC 110/2016, relativa a la Ley 5/2012, de 15 de octubre, de Uniones de Hecho Formalizadas de la Comunitat Valenciana}

La STC 110/2016, de 9 de junio (RTC 2016/110), declara inconstitucional una gran parte de la Ley 5/2012, de 15 de octubre, de Uniones de Hecho Formalizadas de la Comunitat Valenciana. Solo deja a salvo los aspectos de derecho público, amparados por títulos competenciales ajenos al art. 149.1.8. ${ }^{a} \mathrm{CE}^{72}$. En el FJ 10 precisa el alcance temporal de los efectos de la declaración de inconstitucionalidad ${ }^{73}$. De nuevo, el principio de seguridad jurídica conduce al respeto y protección de los derechos individuales, pero limitándose el TC a una genérica afirmación de mantenimiento de las «situaciones consolidadas», sin precisar las que se consideran como tales en

72 En concreto, los relativos a las competencias asumidas en el art. 10.1 y 3 del EACV (defensa y promoción de los derechos sociales de los valencianos, en especial, los derechos de las situaciones de unión legalizadas). Los preceptos que se salvan del naufragio pueden agruparse, como hace el propio TC, en dos categorías. La primera está constituida por disposiciones competencialmente neutras, «que simplemente definen lo que la Comunitat Valenciana considera una «unión de hecho formalizada» a los efectos de su propia administración y competencias, y los que sirven a esta definición sin más (el establecimiento de un registro a los efectos de su publicidad)». La segunda categoría está integrada por las normas contenidas en el art. 15 que regula determinados efectos no civiles de las uniones de hecho formalizadas (vinculados con la regulación de la función pública — licencias, permisos, situaciones administrativas, provisión de puestos de trabajo y ayuda familiar-; derechos y obligaciones de derecho público tales como normas presupuestarias, indemnizaciones, subvenciones y tributos autonómicos; y los derechos a percibir pensiones de viudedad y a las indemnizaciones por accidentes laborales o enfermedades profesionales, aunque en este último punto, la ley valenciana se remite a la legislación aplicable, de carácter estatal). En coherencia con lo anterior, también se reconoce la constitucionalidad de las disposiciones adicional única, final segunda y transitoria única.

73 «[...] teniendo en cuenta la existencia de un régimen legal anterior al ahora anulado (el de la Ley 1/2001, de 6 de abril, por la que se Regulan las Uniones de Hecho) y los efectos que haya podido producir la aplicación de la ley impugnada entre los miembros de las uniones de Hecho formalizadas acogidas a esta, y en sus relaciones con terceros, el principio de seguridad jurídica consagrado en el art. 9.3 CE aconseja limitar los efectos de esta sentencia, que tendrá solo efectos pro futuro, sin afectar a las «situaciones jurídicas consolidadas» (en igual sentido, STC 93/2013, sobre la Ley Foral de Navarra 6/2000, de 3 de julio, para la Igualdad Jurídica de las Parejas Estables, FJ 14)». 
este caso concreto. El propio TC se remite a la sentencia que había dictado tres años antes con relación a la Ley Foral de Navarra 6/2000, de 3 de julio, para la Igualdad Jurídica de las Parejas Estables — STC 93/2013, de 23 de abril (RTC 2013/93)— — ${ }^{74}$, cuyo FJ 14 señalaba:

[...] no podemos soslayar la existencia de situaciones personales y patrimoniales de distinta índole consolidadas al amparo de la Ley Foral impugnada durante el tiempo transcurrido en la sustanciación del presente recurso de inconstitucionalidad. Dotar de eficacia ex tunc a nuestra declaración de inconstitucionalidad podría producir importantes perjuicios a las parejas estables cuya relación se haya desarrollado durante este tiempo de conformidad con las previsiones de dicha Ley, por lo que hemos de seguir la doctrina recogida, entre otras, en las SSTC 54/2002, de 27 de febrero, FJ 9, 365/2006, de 21 de diciembre, FJ 8, y $161 / 2012$, de 20 de septiembre, FJ 7, en las que declaramos que, en supuestos como el que ahora nos ocupa, y atendiendo a la pluralidad de valores constitucionales que concurren, se ha de traer a colación el principio de seguridad jurídica (art. 9.3 CE), al que responde la previsión contenida en el art. 40.1 LOTC. Conforme a este precepto las sentencias declaratorias de la inconstitucionalidad de leyes «no permitirán revisar procesos fenecidos mediante sentencia con fuerza de cosa juzgada», en los que se haya hecho aplicación de las leyes inconstitucionales. Ahora bien, como establecimos en la STC 365/2006, FJ 8, «la modulación del alcance de nuestra declaración de inconstitucionalidad no se limita a preservar la cosa juzgada. Más allá de ese mínimo impuesto por el art. 40.1 LOTC debemos declarar que el principio constitucional de seguridad jurídica (art. 9.3 CE) también reclama que —en el asunto que nos ocupaesta declaración de inconstitucionalidad solo sea eficaz pro futuro, esto es, en relación con nuevos supuestos o con los procedimientos administrativos y procesos judiciales donde aún no haya recaído una resolución firme», puesto que «el principio de seguridad jurídica (art. 9.3 CE) reclama la intangibilidad de las situaciones jurídicas consolidadas; no solo las decididas con fuerza de cosa juzgada, sino también las situaciones administrativas firmes».

Como puede observarse, el TC, aunque con una argumentación más elaborada que en la STC 110/2016, se ciñe a reiterar su doctrina tradicional en términos extraídos literalmente de otras sentencias anteriores. Pero no baja

74 Ese mismo año, unos meses antes, se había dictado la STC 81/2013, de 11 de abril (RTC 2013/81), en relación con diversos artículos de la Ley 11/2001, de 19 de diciembre, de Uniones de hecho de la Comunidad de Madrid, recurridos por falta de competencia sobre legislación civil (véase. art. 149.1.8. ${ }^{\mathrm{a}} \mathrm{CE}$ ). El TC declaró inconstitucionales y nulos los arts. 4 y 5 de la ley, pero sin precisar el alcance temporal de tal declaración. 
a concretar o aplicar estas ideas a los problemas específicos, de índole personal y patrimonial, que pueden suscitarse en el ámbito de las uniones de hecho. Y, literalmente, se limita a extender el respeto de las situaciones decididas con fuerza de cosa juzgada a las situaciones administrativas firmes. En este punto he de dar por reproducidos los argumentos expuestos, en relación con la STC 82/2016, para sustentar el mantenimiento de situaciones consolidadas de derecho privado no restringidas a las decididas por sentencia con fuerza de cosa juzgada y a las situaciones administrativas firmes. Sea como sea, queda por determinar qué hay que entender por «situaciones consolidadas» más allá de las resueltas por sentencia con valor de cosa juzgada o en las que quepa hablar de una situación con firmeza administrativa. En última instancia, la cuestión desemboca en un problema para cuya solución, como exponía en el epígrafe anterior, puede resultar útil la distinción entre retroactividad de grado máximo, medio y mínimo. Aplicando tales ideas a las uniones de hecho, habría que distinguir entre (a) derechos reconocidos y/o consumados antes de la publicación de la sentencia de inconstitucionalidad en el $B O E$, que deben mantenerse; (b) derechos no reclamados pero en relación con los cuales concurrieron los requisitos generadores de estos con anterioridad a la citada publicación o sobre los que se halle pendiente un litigio o se estén tramitando administrativamente, respecto de los cuales la solución es dudosa y habrá de adoptarse casuísticamente a la vista de los intereses afectados; y (c) meras expectativas, a las que no podrán aplicarse las disposiciones declaradas inconstitucionales ${ }^{75}$.

Entre los primeros (a), esto es, efectos ya producidos bajo la ley anterior o, en otras palabras, derechos ya «integrados en el patrimonio del sujeto» (en ocasiones, el TC utiliza otra terminología y habla de «situaciones agotadas», «relaciones consagradas» o "derechos adquiridos») cabría considerar, por ejemplo, las pensiones de alimentos ya satisfechas o sobre las que exista condena firme por aplicación del art. 9 de la Ley valenciana 5/2012; el derecho al uso de la vivienda habitual del conviviente que sobreviva, durante el año posterior al fallecimiento del otro cuando la muerte haya tenido lugar antes de la publicación de la STC 110/2016, que haya sido reconocido (véase art. 12.2); o los actos de disposición sobre la vivienda habitual realizados de acuerdo con el art. 10 de la ley valenciana bajo su vigencia, por poner algunos ejemplos. En relación con la posibilidad de impugnación a la que se refiere el art. 10.4, el acto de disposición debería entenderse confirmado si,

75 Egusquiza Balmaseda (2013: 32-33) trata el tema con referencia a la declaración parcial de inconstitucionalidad de la ley navarra sobre parejas de hecho, con interesantes observaciones, ofreciendo propuestas de solución respecto de un elenco de problemas específicos. 
en el momento de publicarse la sentencia, hubiera transcurrido ya el plazo de cuatro años que establece el precepto (o se hubiera extinguido la unión antes) sin ser impugnado por el conviviente que no consintió la disposición. No cabría atacar tampoco las declaraciones de incapacidad, prodigalidad, ausencia, fallecimiento y desempeño de las funciones de tutela y de curatela en virtud de acciones ejercitadas antes de la publicación de la sentencia con base en la legitimación que concedía el art. 13 de la Ley valenciana 5/2012. En el segundo grupo (b) se encontraría, por ejemplo, el caso en que los procedimientos a que se refiere el art. 12 o la reclamación de alimentos conforme al art. 9 se encontraran tramitándose. Como meras expectativas (c) habría que considerar, entre otras, la hipótesis en que el fallecimiento de uno de los cónyuges a los efectos del art. 12.2, o la necesidad de alimentos en relación con el art. 9, se produjeran tras la publicación de la sentencia de inconstitucionalidad.

\subsection{La STC $192 / 2016$ sobre la Ley $5 / 2011$, de 1 de abril, de la Generalitat, de las relaciones familiares de los hijos e hijas cuyos progenitores no conviven}

La Ley 5/2011, de 1 de abril, de la Generalitat, de las Relaciones Familiares de los Hijos e Hijas cuyos Progenitores no Conviven, conocida comúnmente como Ley de Custodia Compartida, ha estado en vigor cinco años ${ }^{76}$.

Durante este tiempo se ha producido una evolución jurisprudencial significativa de la concepción acerca de la custodia compartida, que afecta a la forma de interpretar el art. $92 \mathrm{CC}$. El proceso evolutivo fue precedido por la regulación expresa de la custodia compartida en el CC por Ley 15/2005, de 18 de julio, desencadenado por el cambio de doctrina que protagonizó en $2012 \mathrm{el} \mathrm{TC}^{77}$ y reflejado en numerosas sentencias del TS a partir de la STS de

76 La Ley entró en vigor el 5 de mayo de 2011. Interpuesto recurso de inconstitucionalidad, el Pleno del TC lo admitió mediante Providencia de 19 de julio de 2011 (BOE núm. 178, de 26.07.2011), suspendiéndose la vigencia de la Ley (véanse arts. 161.2 CE y 30 LOTC). Posteriormente, mediante Auto 161/2011, de 22 de noviembre (BOE núm. 291, 3.12.2011), alzó la suspensión de la entrada en vigor, situación que se ha mantenido hasta la publicación de la STC 192/2016 (BOE núm. 311, de 26.12.2016). En la sentencia del TSJCV, Sala de lo Civil y Penal, de 24 de enero de 2012 (RJ 2012/5920), FJ 2, se deja claro que la Ley resultaba aplicable tanto durante el período anterior a que fuera suspendida su entrada en vigor como después de alzarse dicha suspensión.

77 La STC 185/2012, de 17 de octubre (RTC 2012/185) declaró inconstitucional y nulo el inciso «favorable» del informe del Ministerio Fiscal contenido en el art. 92.8 CC, 
29 de abril de 2013, que abrió la senda que después seguirían otras muchas. Puede describirse a modo de titular como el tránsito desde una posición inicialmente reticente y restrictiva frente al sistema de custodia compartida hasta su paulatina normalización ${ }^{78}$.

El TS entiende en la actualidad que el régimen de guarda y custodia compartida debe ser el normal y deseable, sustentando en diferentes argumentos la bondad objetiva del sistema, mediante una doctrina constante y uniforme. Señala que «la redacción del artículo 92 no permite concluir que se trate de una medida excepcional ${ }^{79}$, sino que al contrario habrá de considerarse normal e incluso deseable, porque permite que sea efectivo el derecho que los hijos tienen a relacionarse con ambos progenitores, aún en situaciones de crisis, siempre que ello sea posible y en cuanto lo sea». Se pretende aproximar este régimen al modelo existente antes de la ruptura matrimonial de modo que los padres puedan participar en igualdad de condiciones en el desarrollo y crecimiento de los hijos. Además de fomentarse la integración de los menores con ambos padres, cuya idoneidad no se cuestiona, se evita el sentimiento de pérdida (así, la STS, Sala de lo Civil, de 13 de julio de 2017 [ROJ: STS 2840/2017], elegida como muestra por ser la última dictada cuando se cierra este trabajo y contener un didáctico resumen de la doctrina del TS.

De este modo, se ha producido por vía jurisprudencial una aproximación de la interpretación del art. 92 CC a los sistemas acogidos en diferentes leyes autonómicas y a las corrientes internacionales sobre la materia (véase la Convención sobre los Derechos del Niño, de 20 de noviembre de 1989, ratificada por España el 30 de noviembre de 1990, o la CDFUE [art. 24.3]), que potencian la corresponsabilidad parental y el derecho del menor a relacionarse por igual con ambos progenitores. Por otra parte, existe un acuerdo bastante

según redacción dada por la Ley 5/2005, de 8 de julio, considerando que corresponde exclusivamente al juez o tribunal verificar si concurren los requisitos legales para aplicar el régimen de custodia compartida.

78 Resultó capital en esta evolución la STS, Sala de lo Civil, de 29 de abril de 2013 (ROJ: STS 2246/2013), cuya doctrina se ha consolidado en numerosos pronunciamientos posteriores (así, por ejemplo, SSTS, Sala de lo Civil, de 19 de julio de 2013 [ROJ: STS 4082/2013], 25 de abril de 2014 [ROJ: STS 1699/2014], 2 de julio de 2014 [ROJ: STS 2650/2014], 9 de septiembre de 2015 [ROJ: STS 3707/2015] o, la más reciente de todas, de 13 de julio de 2017 [ROJ: STS 2840/2017]).

79 Considera ambos regímenes (custodia compartida o individual) como normales, interpretando que la excepcionalidad del art. 92.8 CC debe ponerse en relación con el art. 92.5 y, por tanto, se refiere solo a la determinación judicial del régimen de custodia a falta de acuerdo de los cónyuges, no a que existan circunstancias específicas para acordarla. 
generalizado en que una cuestión tan delicada como esta, considerada de orden público, debería encontrar una solución lo más homogénea posible evitándose discriminaciones entre los ciudadanos por razón de su vecindad civil (en este sentido, por ejemplo, la STS, Sala de lo Civil, de 29 de marzo de 2016 [ROJ: 1291/2016] ${ }^{80}$ ). Las discrepancias tanto doctrinales como de los grupos de interés sobre algunas cuestiones importantes (si la custodia compartida debe constituir o no la regla general; si puede concederse, aunque no la solicite ningún progenitor; si cabe en casos de violencia de género; etc.) ha retrasado la tramitación de una ley estatal sobre el ejercicio de la corresponsabilidad parental que en la actualidad se encuentra en fase de anteproyecto (habiendo sido ya objeto de modificaciones). Esta es la razón de que el camino de normalización de la custodia compartida en el derecho común se esté trazando de momento por la jurisprudencia, pero todo hace prever que acabará por cuajar en la correspondiente ley estatal, que se acompase a la realidad social actual. No hay que dejar de subrayar, por otra parte, que la morosidad estatal refuerza la justificación de los legisladores autonómicos para dictar disposiciones que ordenen el régimen de guarda y custodia de los hijos sobre parámetros ajustados a las modernas orientaciones sobre la materia ${ }^{81}$, lo que no puede ser irrelevante al concretar el alcance retroactivo de la declaración de inconstitucionalidad de la ley valenciana.

La Ley 5/2011, en los supuestos de falta o cese de la convivencia entre los progenitores, configuró la convivencia compartida como la regla general incluso cuando se opusiera alguno de los padres o existiera una mala relación entre ellos (véase art. 5). La atribución, sin embargo, no era automática. El juez, antes de fijar el régimen de convivencia idóneo, debía valorar una serie

80 Casa una sentencia de la AP de Madrid, afirmando que «ciertamente, desconoce, como si no existiera, la doctrina de esta Sala y pone en evidente riesgo la seguridad jurídica de un sistema necesitado de una solución homogénea por parte de los Tribunales a los asuntos similares».

81 Así, preceptos integrados en el Código del Derecho Foral de Aragón, aprobado por Decreto Legislativo 1/2011, de 22 de marzo, que refunde las leyes civiles aragonesas, entre ellas, la Ley de las Cortes de Aragón 2/2010, de 26 de mayo, de Igualdad en las Relaciones Familiares ante la Ruptura de la Convivencia de los Padres; en la Ley 25/2010, de 29 de julio, por la que se aprueba el Libro Segundo del Código Civil de Cataluña Relativo a la Persona y la Familia; Ley Foral del Parlamento de Navarra 3/2011, de 17 de marzo, sobre Custodia de los Hijos en los Casos de Ruptura de la Convivencia de los Padres; Ley 5/2011, de 1 de abril, de la Generalitat Valenciana, de las Relaciones Familiares de los Hijos e Hijas cuyos Progenitores no Conviven; y Ley vasca 7/2015, de 30 de junio, de Relaciones Familiares en Supuestos de Separación o Ruptura de los Progenitores. 
de factores, que enumeraba el propio art. 5 de la ley. Ahora bien, como la custodia compartida era la regla general y la individual la excepción, era el progenitor que reclamaba esta el que tenía la carga de probar que se daban circunstancias excepcionales que, en el caso concreto, hacían incompatible la custodia compartida con el interés del menor ${ }^{82}$.

La ley valenciana incluía dos disposiciones transitorias ${ }^{83}$. La primera aludía a la revisión judicial de medidas adoptadas conforme con la legislación anterior (la contenida en el CC), en los siguientes términos: «A través del procedimiento establecido en la legislación procesal civil para la modificación de medidas definitivas acordadas en un procedimiento de separación, nulidad o divorcio, y a partir de la entrada en vigor de esta ley, se podrán revisar judicialmente las adoptadas conforme a la legislación anterior, cuando alguna de las partes o el Ministerio Fiscal, respecto de casos concretos, soliciten la aplicación de esta norma».

Esta posibilidad fue utilizada por numerosos padres que habían visto cómo se atribuía al otro (habitualmente la madre) la custodia individual del hijo aplicando el CC, más restrictivo, y reclamaban ahora, vigente la ley valenciana, compartir la convivencia en pie de igualdad.

Por su parte, la Disposición Transitoria Segunda declaraba aplicable la ley «a los procedimientos judiciales en materia de nulidad, separación, divorcio y medidas paterno o materno-filiales que estén pendientes de sentencia en el momento de su entrada en vigor ${ }^{84}$.

82 La STSJCV, Sala de lo Civil y Penal, de 6 de septiembre de 2013 (RJ 2013/6660), dispuso como doctrina relativa al citado art. 5 «que el establecimiento, o en su caso el mantenimiento, del régimen de custodia individual requiere de la concurrencia de circunstancias excepcionales, en todo caso vinculadas al superior interés del menor, concretado en cada caso en función de los informes expresamente requeridos en la norma legal, sin cuya concurrencia no cabe fijar ni mantener el régimen de custodia monoparental, y de los factores a tener en cuenta para determinar el régimen de custodia procedente, expresamente recogidos en este precepto».

83 Como señaló la STSJCV, Sala de lo Civil y Penal, de 24 de enero de 2012 (RJ 2012/5920), «siendo cierto que se pretende establecer "para lo sucesivo» un nuevo marco normativo más favorable para la atribución de la guarda compartida, el legislador prevé al efecto dos instrumentos para facilitarlo, permitir, que no ordenar, una modificación de medidas (disposición transitoria primera), o si el procedimiento se encuentra en fase idónea para ello (pendencia de sentencia en primera instancia), establecer la vigencia de la ley (disposición transitoria segunda). Así cobran sentido armónico e integral ambas disposiciones».

84 Entendió la STSJCV, Sala de lo Civil y Penal, de 24 de enero de 2012 (RJ 2012/5920), que debían estar "pendientes de sentencia» en primera instancia. 
Tras estas reflexiones preliminares ha llegado el momento de centrarse en el alcance temporal de la declaración de inconstitucionalidad de la Ley 5/2011 efectuada por la STC 192/2016, de 16 de noviembre (RTC 2016/192). Una vez más, el TC se manifiesta de modo expreso sobre la cuestión:

«En cuanto al alcance de nuestro pronunciamiento de inconstitucionalidad debe precisarse que no afectará a las situaciones jurídicas consolidadas, pues este Tribunal entiende que las decisiones adoptadas por los órganos judiciales durante la vigencia de la Ley 5/2011 que ahora se declara inconstitucional, en relación a la fijación de un determinado régimen de guardia [sic] y custodia para los hijos menores - independientemente de cuál fuera el régimen que indiquen como preferente o deseable los legisladores estatal y autonómico-, se fundaron en la recta aplicación del principio que rige esta materia que no es otro que el del beneficio y protección del interés del menor. Asimismo, conforme al principio constitucional de seguridad jurídica, procede el mantenimiento de las referidas situaciones ya consolidadas con anterioridad al momento de la presente resolución. Por todo lo cual, los regímenes de guardia $[s i c]$ y custodia establecidos judicialmente en los casos que hubieran sido pertinentes, adoptados bajo la supervisión del Ministerio Fiscal y en atención al superior beneficio de los menores, seguirán rigiéndose, tras la publicación de esta Sentencia, por el mismo régimen de guarda que hubiera sido en su momento ordenado judicialmente, sin que este pronunciamiento deba conllevar necesariamente la modificación de medidas a que se refiere el art. 775 LEC» (FJ 5).

Tal declaración merece las siguientes reflexiones, que pueden resumirse en una conclusión, unos argumentos de apoyo y una cuestión problemática.

La conclusión: a salvo de la eficacia retroactiva de la declaración de nulidad de la ley quedan las «situaciones jurídicas consolidadas», en concreto los regímenes de guarda y custodia establecidos judicialmente vigente la ley valenciana (medidas judiciales y pactos de convivencia familiar judicialmente homologados; los no homologados judicialmente tiene el valor de convenios privados sin mayor especialidad ${ }^{85}$.

Los argumentos: para razonarlo, se combina la tradicional invocación del principio de seguridad jurídica con otro argumento específico vinculado a la materia objeto de regulación en la Ley 5/2011; en este caso, las situaciones consolidadas se encuentran legitimadas por el respeto del interés superior del menor que rige, igualmente, en el CC y que debe guiar, por imperativo legal,

85 Aunque la dicción de la sentencia parece apuntar a las medidas judiciales definitivas, puede extenderse a las fijadas por pacto de convivencia familiar en el que se regule la convivencia con los hijos, que habrá requerido la oportuna homologación judicial, para lo cual debe haberse considerado que satisface el interés del menor. 
las decisiones adoptadas por los órganos judiciales en relación con la fijación de un determinado régimen de guarda y custodia para los hijos menores sea cual sea la legislación, estatal o autonómica, que se aplique. En mi opinión, tal argumento puede asociarse con una idea que subyace en diversas sentencias en las que se matiza el alcance temporal de la declaración de inconstitucionalidad: el principio de conservación de las situaciones creadas al amparo de la norma, salvándolas de los efectos retroactivos de la declaración de nulidad, cuando esta retroactividad no sirve a la satisfacción de intereses generales o particulares dignos de tutela.

La cuestión problemática: las conclusiones anteriores no resuelven todas las dificultades. Una cosa es que las atribuciones de guarda y custodia realizadas vigente la ley valenciana mantengan su validez y otra cuestión distinta es que pueda solicitarse, con base en la alteración legislativa que supone la declaración de inconstitucionalidad, una modificación de medidas, alegando un cambio de circunstancias (véanse art. 90.3 CC y art. 775 LEC, que permiten instar la modificación de las medidas convenidas por los cónyuges o de las adoptadas judicialmente en defecto de acuerdo, siempre que hayan variado sustancialmente las circunstancias tenidas en cuenta al aprobarlas o acordarlas). Es decir, que pueda producirse un fenómeno paralelo e inverso al que tuvo lugar al entrar en vigor la Ley 5/2011, en que muchos padres valencianos solicitaron que se modificara la medida de custodia individual cambiándola por una custodia compartida. El propio TSJCV avaló esta práctica considerando que el cambio de régimen jurídico introducido por la ley valenciana era una alteración de las circunstancias vigentes cuando se adoptó la medida suficiente para solicitar la modificación de medidas.

La STSJCV, Sala de lo Civil y Penal, 6 septiembre de 2013 (RJ 2013/6660), interpretando la DT Primera de la Ley 5/2011, declaró que la entrada en vigor de la nueva regulación legislativa autonómica constituye una circunstancia que altera por sí misma las circunstancias bajo las que se adoptaron las medidas definitivas (a lo que ahora nos interesa, la relativa a la guarda y custodia de los hijos), en tanto en cuanto que el régimen jurídico aplicable de la dicha Ley resulte distinto al que regía en el momento de la adopción de las medidas definitivas, y por tanto permite la revisión de las medidas definitivas adoptadas con arreglo al nuevo régimen legal, en cada caso concreto y por vía de la modificación de medidas definitivas. Con la Ley valenciana «se modifican las reglas que regían con anterioridad la adopción de medidas y ello constituye una circunstancia sobrevenida que altera sustancialmente el rebus sic stantibus connatural y propio de las medidas adoptadas, lo que expresamente recoge la disposición transitoria primera de la citada Ley valenciana que establece la posibilidad de revisión judicial de las medidas definitivas adoptadas conforme a la legislación anterior, cuando expresamente se solicite la aplica- 
ción de la dicha norma respecto de casos concretos, refiriendo dicha revisión judicial sustantiva y por cambio de la regulación bajo la que se acordaron las medidas al procedimiento de modificación de medidas definitivas acordadas en un procedimiento de separación, nulidad o divorcio y con ello a la regulación procesal del artículo 755 y concordantes de la Ley de Enjuiciamiento Civil. [...] en definitiva la alteración de las reglas de derecho aplicables constituye una alteración de las circunstancias que llevaron a la adopción de uno u otro régimen de custodia» (FJ 5). Ahora bien, el Juez solo debe proceder a la modificación de medidas definitivas solicitada con base en el aludido cambio legislativo cuando, a la vista del caso concreto, concluya que la aplicación de la Ley 5/2011 conduce a un resultado distinto al que dio lugar la del Código Civil (FJ 6). En suma, no es necesario que, además del cambio de régimen legal, se den otras variaciones en la situación de los padres o de los hijos que alteren sustancialmente las que se tuvieron en cuenta al fijar las medidas definitivas (por ejemplo, un cambio de domicilio, o una mayor o menor disponibilidad horaria para cuidar a los hijos por una variación de la situación laboral); pero sí que lo es que la aplicación del nuevo régimen legal (la Ley 5/2011), aun partiendo de las misma situación familiar, conduzca a resultados diferentes a los que se derivaron de la aplicación de la normativa anterior (el Código Civil).

En relación con esta última cuestión, la STC 192/2016 deja traslucir que el TC es consciente de que podrían multiplicarse las demandas instando la modificación de medidas definitivas ante el cambio en el panorama legislativo introducido por la declaración de inconstitucionalidad de la ley valenciana y, de algún modo, intenta atajar el fenómeno con la afirmación contenida en el último inciso del FJ 5: «[...] sin que este pronunciamiento deba conllevar necesariamente la modificación de medidas a que se refiere el art. 775 LEC». Sin duda, el TC ha considerado conveniente manifestarse sobre la cuestión (aunque no lo haya hecho con toda la claridad necesaria) en previsión de la litigiosidad de que es susceptible, más a la vista de los antecedentes. Procede, por tanto, analizar la viabilidad de esta eventual solicitud de modificación de medidas relativas a la guarda y custodia y otras conexas, con base en la declaración de inconstitucionalidad de la ley que se aplicó para establecerla (la Ley 5/2011). El supuesto se ciñe a los casos en que se atribuyó la custodia compartida sin acuerdo de los padres y ahora el progenitor que estaba en desacuerdo pretende que se pase a una custodia individual (normalmente, que se le conceda a él).

La afirmación del TC significa, desde luego, que la declaración de inconstitucionalidad y nulidad de la Ley 5/2011 no da pie a una modificación automática de las medidas sobre guarda y custodia (y, en su caso, otras conexas, como la de alimentos o la atribución del uso de la vivienda familiar). Pero ¿excluye que puedan solicitarse y lograrse con base en la declaración de 
inconstitucionalidad? ¿Lo impide el FJ 5 de la sentencia o simplemente deja la cuestión abierta? Creo que, más bien, lo segundo, aunque hay argumentos suficientes para entender que, en la práctica, esta solicitud no tendría muchos visos de prosperar en la mayor parte de los casos. Es cierto que se ha producido un cambio de régimen legal por comparación con el que se aplicó para fijar las medidas definitivas. Y cabe asumir que un cambio de estas características, como dejó claro el TSJCV, es una circunstancia sobrevenida que altera sustancialmente el rebus sic stantibus connatural y propio de las medidas adoptadas, esto es, una alteración sustancial a los efectos de sustentar una modificación de medidas definitivas. Pero también lo es que para establecer esta modificación el juez debe proceder a la vista del caso concreto y valorar si en relación con él, aplicando el nuevo régimen jurídico, la medida fijada debe ser diferente. Dado que las concretas medidas definitivas se establecieron en atención al interés superior del menor, principio rector tanto en las legislaciones autonómicas como en el CC, pero sobre todo a la vista de la manifiesta evolución sufrida por la jurisprudencia del TS, al interpretar el art. 92 CC, en el sentido de considerar la custodia compartida como un régimen normal y deseable, sería difícil que en la actualidad prosperase la solicitud de modificación de medidas con base únicamente en la declaración de inconstitucionalidad de la Ley valenciana ${ }^{86}$. Sobre todo, teniendo en cuenta que la decidirían los jueces valencianos que cabe esperar serían respetuosos con esta doctrina jurisprudencial sobre la normalidad y deseabilidad de la custodia compartida (lo que no ocurre con otros tribunales a los que el TS ha tenido que enmendar la plana en los recursos de casación más de una vez, llamada de atención incluida en algunos casos).

86 Como ha declarado el TS, «la cláusula general de la consideración primordial del interés superior del menor contenida en la legislación no permite al juez alcanzar cualquier resultado en la aplicación de la misma. La concreción de dicho interés del menor no debe hacerse conforme a sus personales puntos de vista, sino tomando en consideración los valores asumidos por la sociedad como propios, contenidos tanto en las reglas legales como en los principios que inspiran la legislación nacional y las convenciones internacionales». Ya hemos visto como la evolución de estos valores y reglas tiende a considerar la custodia compartida como el régimen deseable siempre que las circunstancias del caso concreto no lo contradigan. Y es a los efectos de valorar estas circunstancias cuando el ordenamiento jurídico hace jugar el principio del interés superior del menor, que «es un concepto jurídico indeterminado, esto es, una cláusula general susceptible de concreción que el propio legislador introduce conscientemente para ampliar los márgenes de la ponderación judicial» (STS, Sala de lo Civil, de 6 de febrero de 2014 [ROJ: 247/2014], sobre gestación por sustitución). 
Tampoco puede olvidarse que la vigente Ley 12/2008, de 3 de julio, de la Generalitat, de Protección Integral de la Infancia y la Adolescencia de la Comunitat Valenciana dedica su art. 22 a regular el derecho de los menores a las relaciones familiares en términos que siguen favoreciendo claramente el régimen de custodia compartida en el caso de que los padres no convivan, lo que refuerza el razonamiento.

De la conclusión anterior, que constituye la regla general, deben exceptuarse algunos casos concretos. El primero es aquel en que, aplicando la Ley 5/2011, el juez estableció un régimen de custodia compartida sin que lo hubiese solicitado ninguno de los progenitores, lo que era posible con la ley valenciana, pero no con el CC, tal y como ha interpretado la jurisprudencia ${ }^{87}$. Sin embargo, hay que tener en cuenta que no se trata de dar alcance retroactivo a la declaración de inconstitucionalidad de la ley, sino de justificar una modificación futura de medidas por alteración sustancial de las circunstancias guiada siempre por el interés superior del menor, no resultando del todo seguro que a tales efectos resulte relevante aquel dato. La cuestión es dudosa. El segundo supuesto que debe exceptuarse de la regla general y que podría justificar la modificación de medidas es el relativo a la existencia de una situación o de indicios de violencia doméstica, que recibe un trato diferente en el CC (art. 92.7) y en la Ley 5/2011 ${ }^{88}$.

Alguna reflexión merece, por último, el alcance de la declaración de inconstitucionalidad de la Ley 5/2011 en relación con la atribución del uso de la vivienda familiar (art. 6), incluido el derecho a obtener una compensación económica en el caso de atribuirse a uno de los progenitores, si aquella es privativa del otro o común de ambos. Deben respetarse las medidas establecidas en sentencia firme (véase art. 40.1 LOTC). Pero ello no obsta a que pueda solicitarse una modificación de medidas definitivas por la vía del art. 775 LEC, con base en el cambio de régimen jurídico, de acuerdo con las ideas antes expuestas, siempre y cuando en el caso concreto el CC deba conducir a una solución diferente a la que resultó de la aplicación de la ley valenciana.

Para valorar la concesión o no de la modificación de la medida eventualmente solicitada habrá que distinguir entre aquella circunstancia direc-

87 Entre otras, STS, Sala Civil, de 19 de abril de 2012 (ROJ: STS 2905/2012).

88 En aquel no procederá la guarda conjunta cuando se den las circunstancias que establece el art. 92.7 CC. La Ley 5/2011, en cambio, era más permisiva. El art. 5.6 hacía posible establecer una custodia compartida si el Juez consideraba que, pese a todo, no se derivaba de su fijación riesgo objetivo para los hijos e hijas o para el otro progenitor. Sobre las diferencias entre el CC y la Ley 5/2015, véase Conde-Pumpido García (2011: 15-17). 
tamente conectada (aunque no de modo exclusivo, pues también se tiene en cuenta el interés del padre más necesitado) con el interés del menor, esto es la atribución del uso de la vivienda propiamente dicha, de aquella otra respecto de la que el interés del menor es un dato neutro, además de operar en un plano puramente patrimonial, como es el reconocimiento de una compensación económica a favor del titular o cotitular de la vivienda a quien no se le concedió el uso. Habrá que ver, por otra parte, si el uso atribuido se consideró como parte de la pensión de alimentos a favor del hijo o como contribución a las cargas del hogar o, por exceder de estas partidas o funcionar al margen de ellas, generó el derecho a la compensación regulada en el art. 6 de la Ley valenciana. Sea como sea, cuando el juez valore la oportunidad de conceder o no la modificación de medida eventualmente solicitada, habrá de atender al interés del menor no en el momento en que se estableció la medida definitiva, sino en aquel en que se va a evaluar la conveniencia de su modificación. Finalmente, dado que la atribución del uso de la vivienda tiene siempre carácter temporal en la ley valenciana no será descabellado considerar que quizá deshacer la medida cause más trastorno y perjuicios que esperar a que transcurra el tiempo establecido.

\section{CONCLUSIONES}

1. Es conveniente una modificación de la LOTC que introduzca una norma que legitime de forma clara al TC para flexibilizar el alcance temporal de la declaración de inconstitucionalidad de las leyes. La conclusión queda reforzada a la vista de la realidad imperante en los ordenamientos jurídicos de nuestro entorno.

2. Pese al proceder casuístico del TC al matizar los efectos temporales de la declaración de inconstitucionalidad, es posible decantar, a partir del estudio de sus sentencias, unos criterios rectores interpretativos que guíen la solución de los casos que se vayan planteando en la práctica.

3. El TC utiliza diferentes expedientes técnicos para flexibilizar el binomio inconstitucionalidad/nulidad, que van desde la declaración de inconstitucionalidad sin nulidad hasta la limitación de los efectos retroactivos de la nulidad declarada, pasando por el recurso a la nulidad diferida en el tiempo, la nulidad acotada territorialmente (inaplicabilidad de la ley en cierto territorio) o las sentencias interpretativas. Para optar por una u otra solución, apela a distintas consideraciones entre las que destacan la causa de la inconstitucionalidad (según obedezca a motivos procedimentales, de incompetencia o al atentado contra derechos y libertades amparados por la $\mathrm{CE}$ ); lapso temporal transcurrido desde la entrada en vigor de la dispo- 
sición hasta su declaración de inconstitucionalidad; consecuencias económicas graves para la Hacienda Pública; inidoneidad de la nulidad o de su eficacia retroactiva para dar satisfacción a los intereses del recurrente o a los intereses generales; susceptibilidad o no de la ley inconstitucional de seguir produciendo efectos en el futuro; eventual perjuicio a derechos o intereses legítimos generados a partir de la confianza en la legitimidad de la ley mientras se encontraba en vigor. En cualquier caso, la moderación de los efectos temporales de la declaración de inconstitucionalidad debe obedecer a la necesaria ponderación de los distintos principios constitucionales involucrados —en especial, el de seguridad jurídica (art. 9.3 CE) — guardando la necesaria proporcionalidad.

4. Los casos fiscales o administrativos marcan prioritariamente la construcción de la doctrina del TC sobre la materia. Pese a que el tipo de intereses afectados y de «situaciones consolidadas» bajo la vigencia de la ley inconstitucional pueden ser sustancialmente diferentes cuando la sentencia afecta a leyes civiles, la jurisprudencia constitucional no manifiesta en un plano dogmático, respecto de ellas, innovación esencial en relación con su doctrina tradicional. Es al descender de los principios a la solución de las controversias que se pueden plantear en relación con el caso concreto cuando las leyes civiles declaradas inconstitucionales requieren un esfuerzo especial del intérprete para adaptar la doctrina establecida a partir de casos mayoritariamente de orden fiscal o administrativo, y afloran sus peculiaridades, entre las que destacan las siguientes:

- En materia civil resulta muchas veces conveniente la ampliación de las situaciones consolidadas que deben quedar a salvo de los efectos retroactivos de la declaración de inconstitucionalidad más allá de las amparadas por la cosa juzgada o las situaciones administrativas firmes. Esta ampliación puede sustentarse en el principio de seguridad jurídica (art. 9.3 CE); la posibilidad de interpretar de modo flexible el art. 40.1 LOTC; e incluso el art. 2.3 CC, en cuanto establece la regla general de irretroactividad de las leyes y las DDTT del propio Código Civil, que dejan a salvo los derechos adquiridos bajo la legislación anterior.

- Pierde protagonismo uno de los argumentos con presencia más intensa en las sentencias referidas a supuestos fiscales y administrativos: el perjuicio para las arcas públicas derivado del alcance retroactivo de la declaración de nulidad del precepto inconstitucional.

- Cuando la inconstitucionalidad declarada deriva de un defecto de competencia basado en el art. 149.1.8. ${ }^{\text {a }} \mathrm{CE}$, tanto la declaración de inconstitucionalidad, como su alcance temporal pueden resultar 
especialmente sensibles desde el punto de vista político e incluso chocar con la realidad social actual, que permitiría una evolución de la interpretación del citado precepto en un sentido más autonomista (art. 3.1 CC).

5. Descendiendo a algunos aspectos concretos relativos al alcance temporal de la declaración de inconstitucionalidad de las leyes civiles valencianas, puede concluirse que:

- Resulta cuestionable la fundamentación que ofrece la STC 82/2016 para afirmar la continuidad del régimen legal de separación de bienes de los matrimonios valencianos concertados vigente la LREMV, al sustentar esta conclusión en el principio de libertad o autonomía privada. El argumento de la seguridad jurídica, que conduce al respeto de las situaciones consolidadas, es el que debería haberse utilizado.

- La eventual sujeción de los matrimonios valencianos celebrados vigente la LREMV al bloque de normas comunes conocidas como régimen económico matrimonial primario de esta Ley y no a sus equivalentes en el Código Civil, habría de sustentarse, en su caso, en argumentos distintos al de la autonomía privada: el principio de seguridad jurídica y la consideración del régimen económico del matrimonio en la LREMV como un sistema unitario y coherente.

- La declaración de inconstitucionalidad de la Ley 10/2007 no afecta a la persistencia de las germanías estipuladas, amparadas por la libertad de pactos.

- El argumento del interés del menor, que utiliza la STC 192/2016, para salvaguardar, como «situaciones jurídicas consolidadas», las situaciones de guarda y custodia compartida establecidas al amparo de la Ley valenciana 5/2012 puede asociarse con un principio de conservación de las situaciones creadas al amparo de la norma, salvándolas de los efectos retroactivos de la declaración de nulidad, cuando esta retroactividad no sirve a la satisfacción de intereses generales o particulares dignos de tutela.

- Es difícil que prospere una eventual solicitud de modificación de las medidas sobre guarda y custodia y otras conexas adoptadas bajo la vigencia de la Ley valenciana 5/2012 con base únicamente en su declaración de inconstitucionalidad. Esta conclusión, que constituye la regla general, debe matizarse en relación con: 1) el caso en que el Juez estableció el régimen de custodia compartida sin que lo 
hubiese solicitado ninguno de los progenitores; 2) el relativo a la existencia de una situación o de indicios de violencia doméstica..

\section{Bibliografía}

Agoués Mendizábal, C. (2014). Los efectos de las sentencias que declaran la nulidad de las disposiciones administrativas de carácter general. Revista Vasca de Administración Pública, 99-100, 65-85.

Agudo González (2000). Inconstitucionalidad y nulidad de leyes. Cuestiones competenciales, eficacia del derecho comunitario y protección del medio ambiente: comentario crítico a la Sentencia del Tribunal Constitucional 195/1998, de 1 de octubre: el asunto de las marismas de Santoña. Revista de derecho Urbanístico y Medio Ambiente, $178,87-114$

Ahumada Ruíz, M. ${ }^{a}$ A. (2001). Responsabilidad patrimonial del Estado por las leyes inconstitucionales (o el derecho a no ser perjudicado por una ley inconstitucional). Revista Española de derecho Constitucional, 62, 301-350.

Alonso García, M. C. (2002). La reciente jurisprudencia sobre la responsabilidad patrimonial del Estado legislador frente a daños derivados de leyes inconstitucionales. Revista de Administración Pública, 119, 215-240.

Alonso García, R. (1998). El Tribunal Constitucional y la eficacia temporal de sus sentencias anulatorias. Revista de Administración Pública, 157, 225-268.

Aparicio Pérez, M. A. (1983). Algunas consideraciones sobre la Justicia Constitucional y el Poder Judicial. Revista Jurídica de Cataluña, 4, 944.

Aragón Reyes, M. (1987). Algunas consideraciones sobre el Tribunal Constitucional. Revista Jurídica de Castilla-La Mancha, 1, 27-53.

Arozamena Sierra, J. (1979). Valor de la jurisprudencia constitucional. Separata de La Constitución española y las fuentes del derecho. Madrid: Instituto de Estudios Fiscales.

Bachof, O. (1985). Jueces y Constitución. Madrid: Civitas.

Balaguer Callejón, M. L. (2001). El recurso de inconstitucionalidad. Madrid: Centro de Estudios Políticos y Constitucionales.

Bercovitz Rodríguez-Cano, R. (2016). Alto al derecho civil valenciano. Revista Doctrinal Aranzadi Civil-Mercantil, 7, 1-4.

Bocanegra Sierra, R. (1982). El valor de las sentencias del Tribunal Constitucional. Madrid: Instituto de Estudios de Admininistración Local.

(1991). Sobre el alcance objetivo de las sentencias del Tribunal Constitucional. En S. Martín-Retortillo (coord.). Estudios sobre la Constitución Española. Homenaje al Profesor Eduardo García de Enterría (vol I, pp. 509-536). Civitas: Madrid.

Caamaño Anido, M. A. (1997). Nulidad de la norma tributaria y devolución de ingresos indebidos. Anuario da Facultade de derecho, 167-180.

Cappelletti, M. (1978). Il controllo giudiziario di costituzionalità delle leggi nel diritto comparato. Milán: Giuffrè editore. 
Cavas Martínez, F. (2014). Ajustes constitucionales recientes a la regulación sobre el acceso de la pareja de hecho a la pensión de viudedad contenida en la Ley 4/2007. Revista de derecho de la Seguridad Social, 1, 183-198.

Chico Y Ortiz, J.Ma. (1984). Proyecciones de la seguridad jurídica. Revista Crítica de derecho Inmobiliario, 563, 797-830.

Coca Payeras, M. (1992). Comentario al artículo 2 CC. En M. Albaladejo y S. Díaz Alabart (dirs.). Comentarios al Código Civil y Compilaciones Forales (t. I, vol.1, pp. 415-514). Madrid: EDERSA.

Colina Garea, R. (2013a). Comentario al artículo 2 CC. En R. Bercovitz (dir.). Comentarios al Código civil (t. I, pp. 100-114). Valencia: Tirant Lo Blanch.

_ (2013b). Comentario a las disposiciones transitorias. En R. Bercovitz (dir.). Comentarios al Código civil (t. IX, pp. 13383-13469). Valencia: Tirant Lo Blanch.

Conde-Pumpido, J. L. (2011). Ley valenciana de custodia compartida. Revista de Treball, Economia i Societat, 62, 1-30. Disponible en: http://www.ces.gva.es/cs_/revista63. htm

De Castro y Bravo, F. (1984). Derecho Civil de España. Madrid: Civitas.

De La Cueva Aleu, I. (2010). Comentario a los artículos 38 a 40 LOTC. En J. J. González (dir.). Comentarios a la Ley Orgánica del Tribunal Constitucional (pp. 425-468). Madrid: La Ley.

Díaz Aznarte, M. T. (2002). Teoría general de la sucesión de normas en el tiempo (una reflexión crítica sobre los principios ordenadores de la eficacia temporal de las leyes). Valencia: Tirant Lo Blanch.

— (2016). Parejas de hecho «acreditadas» y pensión de viudedad. El triunfo del formalismo frente a la justicia material. Revista de Derecho de la Seguridad Social, 1, 167-176.

Díaz Revorio, F. J. (2001). Las sentencias interpretativas del Tribunal Constitucional. Significado, tipología, efectos y legitimidad, análisis especial de las sentencias aditivas. Madrid: Lex Nova.

Díez-Picazo Giménez, L. M. (1990). La derogación de las leyes. Madrid: Civitas.

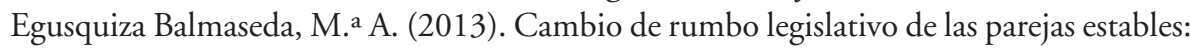
SSTC 81/2003, de 11 de abril de 2013 y 93/2003, de 23 de abril de 2013. Revista Doctrinal Aranzadi Civil-Mercantil, 5/2013, 1-39.

Ezquiaga Ganuzas, F. J. (1991). Diez años de falles constitucionales (sentencias interpretativas y poder normativo del Tribunal Constitucional. Revista Vasca de Administración Pública, 31, 117-142.

Fernández Rodríguez, J. J. (2007). La justicia constitucional europea ante el siglo XXI. Madrid: Tecnos.

García de Enterría, E. (1981). La posición jurídica del Tribunal Constitucional en el sistema español: posibilidades y perspectivas. Revista Española de Derecho Constitucional, $1,35-132$.

_- (1989). Un paso importante para el desarrollo de nuestra justicia constitucional: la doctrina prospectiva en la declaración de ineficacia de las Leyes inconstitucionales. Revista española de Derecho Administrativo, 61, 5-18. 
García Moreno, V. A. (2016). Recientes pronunciamientos del TJUE y del TC acerca de las tasas judiciales. Carta Tributaria. Revista de Opinión, 19, 1-16.

García Rubio, M. P. (2010). Comentario al artículo 2 CC. En A. Domínguez (dir.). Comentarios al Código Civil (pp. 51 y ss.). Valladolid: Lex Nova.

- (2007). Presente y futuro del Derecho Civil español en clave de competencias normativas. Revista de Derecho Civil, IV-3, 1-33.

García Vicente, J. R. (2006). Sentencia del TC de 26 de mayo de 2005 (RTC 2005,138). Cuadernos Civitas de Jurisprudencia Civil, 70, 519-560.

Garrorena Morales, A. (1999). Artículo 164 de la Constitución. Condiciones y efectos de las sentencias del Tribunal Constitucional. En O. Alzaga (dir.). Comentarios a la Constitución Española de 1978 (XII, pp. 299-385). Madrid: Cortes Generales y EDERSA.

Gómez Corona, E. (2009). El control de constitucionalidad de la Ley en España. Análisis de la jurisprudencia constitucional (1980-2008). UNED. Revista de Derecho Político, 74, 263-288.

Gómez Montoro, Á. J. (2001). Artículos 38 a 40 LOTC. En J. L. Requejo (coord.). Comentarios a la Ley Orgánica del Tribunal Constitucional (pp. 553-631). Madrid: TC/BOE.

González Beilfuss, M. (2000). Tribunal Constitucional y reparación de la discriminación normativa. Madrid: CEPC.

González-Vargas Ibáñez, S. (2009). Los efectos de las sentencias anulatorias de los Tribunales Constitucionales. Revista de Administración Púbica, 178, 361-367.

Jiménez Campo, J. (1997). Qué hacer con la Ley inconstitucional. En La sentencia sobre la inconstitucionlidad de la Ley. Actas de las II Jornadas de la Asociación de Letrados del Constitucional (pp. 15-79). Madrid: TC/CEC.

Málvarez Pascual (1988). Los efectos de la declaración de inconstitucionalidad o nulidad de disposiciones tributarias. Madrid: Asociación Española de Asesores Fiscales.

Martínez Barroso, M. R. (2016). Sentencia del Tribunal Constitucional 81/2016, de 25 de abril. Inconstitucionalidad del requisito de existencia de hijos comunes para que la pareja de hecho pueda acceder a la pensión de viudedad en el derecho transitorio de clases pasivas. Ars Iuris Salmanticensis, 4, 292-297.

Mas Badía, M. D. (2009). Autonomía, fueros y derecho civil. La Ley de régimen económico matrimonial valenciano. En M. L. Atienza, R. Evangelio, M. D. Mas Badía y M. P. Montes (coords.). Pensamientos jurídicos y palabras dedicados a Rafael Ballarín Hernández (pp. 625-647). Valencia: SPUV.

— (2010). La germanía. En M. D. Mas Badía (coord.). El régimen económico matrimonial de la Comunidad Valenciana (pp. 273-395). Madrid: Tecnos.

_ (2016) Luces y sombras de la Ley de régimen económico matrimonial valenciano tras su declaración de inconstitucionalidad. Revista de Derecho civil valenciano, 20, $1-13$.

Montoro Chiner, M. J. (1990). Protección de la familia y fiscalidad (A propósito de la STC 45/1989, de 20 de febrero). Revista Española de Derecho Constitucional, 28, 223-235. 
Montoro Puerto, M. (1991). Jurisdicción constitucional y procesos constitucionales. Madrid: COLEX.

Pelegrí Girón, J. (1988). El principio de seguridad jurídica y la eficacia temporal de las sentencias del Tribunal Constitucional. En Jornadas de Estudio sobre el Titulo Preliminar de la Constitución (vol. V). Madrid: Ministerio de Justicia.

Pérez Tremps, P. (2016). Sistema de Justicia Constitucional. Cizur Menor (Navarra): Aranzadi-ThomsonReuters.

Pibernat Doménech, X. (1987a). Los efectos de la declaración de inconstitucionalidad. Revista Jurídica de Cataluña, 4, 971-984.

- (1987b). La sentencia constitucional como fuente del derecho. Revista de Derecho Político, 24, 57-85.

Punset Blanco, R. (1995). Las sentencias declaratorias de la inconstitucionalidad de las leyes: consideraciones sobre la posible reforma de los artículos 39.1 y 40.1 de la LOTC. Anuario de derecho Constitucional y Parlamentario, 7, 33-48.

Rubio Llorente, F. (1988). La jurisdicción constitucional como forma de creación de derecho. Revista Española de Derecho constitucional, 22, pp. 9-51.

Rubio Llorente, F. y Aragón Reyes, M. (1984). La jurisdicción constitucional. En A. Predieri y E. García de Enterría (dirs.). La Constitución Española de 1978 (pp. 831886). Madrid: Civitas.

Ruiz López, M. A. (2013). Retrospectiva y alcance actual de la responsabilidad patrimonial del Estado-legislador. Revista Digital Facultad de Derecho, 6, 66-95.

Salvador Coderch, P. (1991). Comentario al artículo 2 CC. En C. Paz-Ares, R. Bercovitz, L. Díez-Picazo y P. Saldador (dirs.). Comentario del Código Civil (t.I, pp. 13-19). Madrid: Ministerio de Justicia.

Sospedra Navas, F. J. (2011). Justicia constitucional y procesos constitucionales. Cizur Menor (Navarra): Civitas-Thomson Reuters.

Suárez Collía, J. M. (1991). El principio de irretroactividad de las normas jurídicas. Madrid: ACTAS.

Tejedor Bielsa, J. C. (1999). Inconstitucionalidad y nulidad demorada, ¿paliativo a la nueva jurisprudencia sobre supletoriedad? La STC 195/1988, de 1 de octubre. Civitas Revista Española de derecho Administrativo, 101, 117-126.

Tudela Guerrero, J. (2000). Los efectos de las sentencias dictadas en procesos de control de constitucionalidad. Boletín de Información. Ministerio de Justicia, 1882, 39113922.

Ugartemendía, J. I. y Bengoetxea, J. R. (2014). Breves apuntes sobre las sentencias básicas del Tribunal de Justicia de la Unión Europea. UNED. Teoría y Realidad Constitucional, 33, 443-480.

Verdera Izquierdo, B. (2006). La irretroactividad: problemática general. Madrid: Dykinson.

Vidales Rodríguez, C. (2001). La eficacia retroactiva de los cambios jurisprudenciales. Valencia: Tirant Lo Blanch. 